\title{
TOSSD - TRACKING PEACE AND SECURITY EXPENDITURES IN SUPPORT OF THE SDGS
}

Aussama Bejraoui, Valérie Gaveau and Julia Benn

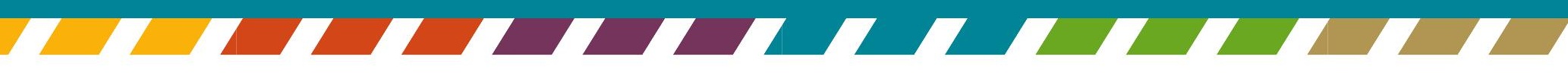

OECD DEVELOPMENT CO-OPERATION WORKING PAPER 66

Authorised for publication by Jorge Moreira da Sllva, Director, Development Co-operation Directorate 



\section{Working Paper}

OECD Working Papers do not represent the official views of the OECD or of its member countries. The opinions expressed and arguments employed are those of the author(s).

Working Papers describe preliminary results or research in progress by the author(s) and are published to stimulate discussion on a broad range of issues on which the OECD works. Comments on this Working Paper are welcome and may be sent to dac.contact@oecd.org - Development Co-ordination Directorate, OECD, 2 rue André-Pascal, 75775 Paris Cedex 16, France.

This document, as well as any data and any map included herein, are without prejudice to the status of or sovereignty over any territory, to the delimitation of international frontiers and boundaries and to the name of any territory, city or area.

\section{Abstract}

This Working Paper presents the main findings and recommendations of the pilot study carried out on the treatment of peace and security expenditures in the statistical measure of total official support for sustainable development (TOSSD).

The pilot study explored the relevance of including various peace and security expenditures in the TOSSD framework, and formulated recommendations to the International TOSSD Task Force on the eligibility criteria, the potential safeguards and the delineation between TOSSD pillar I and II for peace and security expenditures. On this basis, the Task Force adopted in June 2019 specific text on the treatment of peace and security in the TOSSD Reporting Instructions.

The pilot study also allowed to derive first estimates of TOSSD flows for peace and security and a light assessment was carried out of the capacity of the organisations / countries met during the pilot to provide TOSSD data on peace and security. 


\section{Table of Contents}

Working Paper .......................................................................................................................................... 3

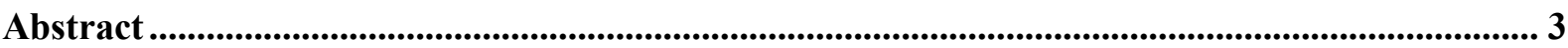

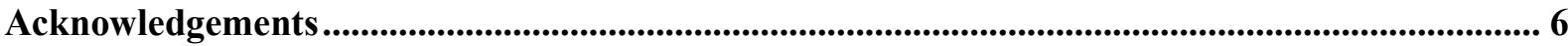

Introduction ......................................................................................................................................... 7

Part I. Main findings and eligibility criteria for the treatment of peace and security in TOSSD.. 8

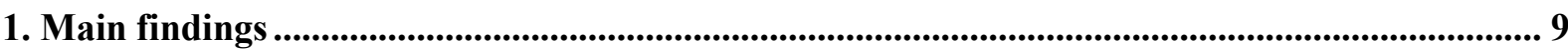

2. Eligibility criteria for the treatment of peace and security in TOSSD ......................................... 12

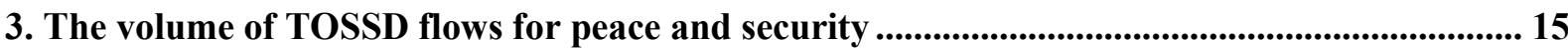

Part II. Information on pilot study and general background on the link between peace and security and sustainable development ......................................................................................................... 16

4. Context and objectives of the peace and security pilot study ............................................................ 17

5. General background on peace and security and sustainable development................................... 20

Part III. Treatment of peace and security expenditures in TOSSD............................................... 25

6. General principles and safeguards that should apply to peace and security expenditures ...... 26

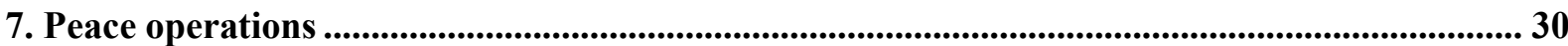

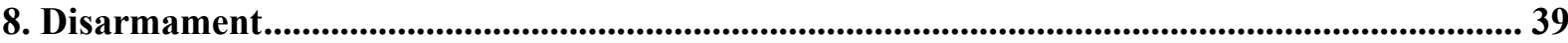

9. Law enforcement, including the fight against terrorism and organised crime........................... 44

10. Engagement with the military …........................................................................................................... 55

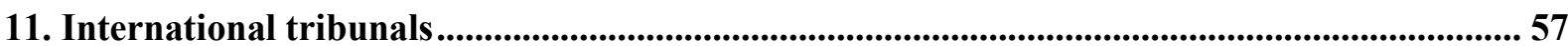

Part IV. The Perspective of France as a Provider .............................................................................. 58

12. Perspective of France on the coverage of peace and security expenditures in TOSSD........... 59

13. Safeguards proposed by France for recording peace and security expenditures in TOSSD.. 61

14. Presentation of the co-operation actors and TOSSD estimates on peace and security expenditures by France

Part V. Light assessment of the capacity of the organisations / countries met during the pilot to provide TOSSD data on peace and security....................................................................................... 70

15. Capacities of countries met during the pilot to provide TOSSD data on peace and security. 71

16. Capacity of multilateral institutions met during the pilot to provide TOSSD data on peace and security 73

Conclusions and next steps ........................................................................................................................... 77

Annex A. SDG 16 and related targets....................................................................................................... 78 
Annex B. List of topics for consultation with experts, at a meeting, through a written questionnaire to the International Network on Conflict and Fragility (INCAF), and during

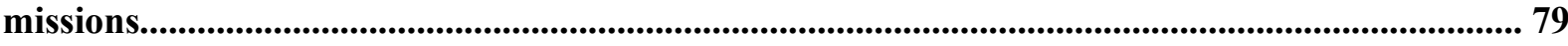

Annex C. List of consultations carried out in the context of the TOSSD pilot on peace and

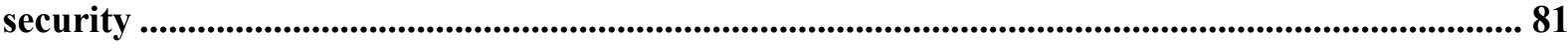

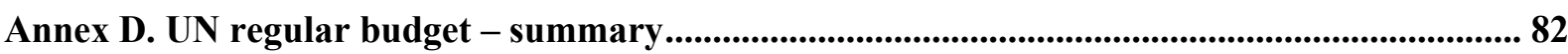

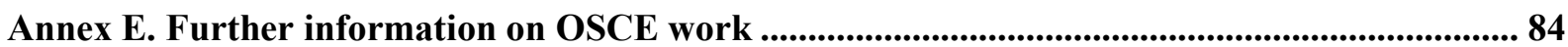

Annex F. Contribution by Australia on possible adjustments to TOSSD sector and modality classifications in the area of peace and security........................................................................................... 86

References ........................................................................................................................................................ 94

\section{Tables}

Table 3.1. First estimates of TOSSD expenditures in the field of peace and security ......................... 15

Table 7.1. Human resources of MINUSMA assigned by component ................................................ 34

Table 14.1. Summary of expenditures by France in support of the SDGs in the field of peace and security, TOSSD estimate for 2018

\section{Boxes}

Box 7.1. The UN reform process and UN peacekeeping As described by UN DPO during the expert workshop held in February 2019

Box 7.2. Example of a UN peacekeeping mission acting under Chapter VII of the UN Charter: the United Nations Multidimensional Integrated Stabilization Mission in Mali - MINUSMA ......... 33

Box 7.3. The Organization for Security and Co-operation in Europe (OSCE) .................................... 36

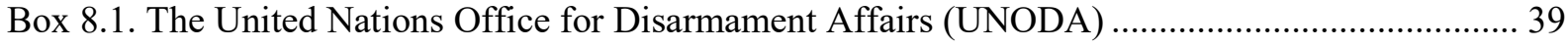

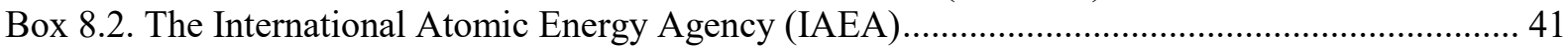

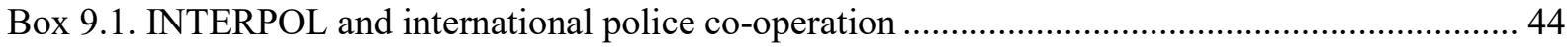

Box 9.2. The United Nations Office of Counter-Terrorism (UNOCT) ............................................. 48

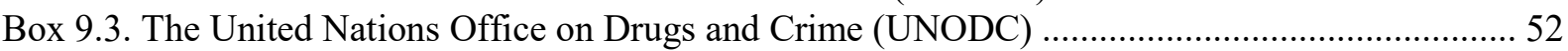

Box 15.1. Australian Official Support to Developing Countries: Peace and Security Classification ... 71 


\section{Acknowledgements}

The authors would like to thank the contributors to this pilot study, in particular the officials interviewed from various organisations active in the field of peace and security who helped analyse the linkages between their work and the SDGs (see boxes in the report).

The report also benefitted from the contribution of several provider and recipient countries through written comments or interviews, who provided examples of relevant activities and associated safeguards, and of civil society organisations and researchers who shared their perspectives on this topic.

The authors would also like to thank the Government of France, in particular the Ministry for Europe and Foreign Affairs, for co-ordinating a consultation with various ministries to present a more in-depth provider perspective.

The report also benefitted from a desk review conducted by Marloes Smeet, consultant, and helpful comments from colleagues of the Development Co-operation Directorate.

Finally, the Development Co-operation Directorate gratefully acknowledges the direct financial contribution of the European Union for this thematic pilot study, which supports the work of the International TOSSD task force and allows for exploring the relevance of including various peace and security expenditures in the TOSSD framework.

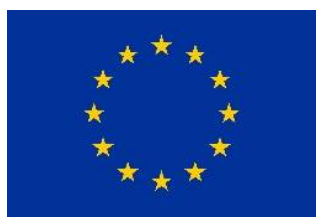

Co-funded by

the European Union 


\section{Introduction}

This document presents the findings of the thematic pilot study carried out on the treatment of peace and security expenditures in TOSSD.

Part I summarises the principal findings of the pilot study, as well as the eligibility criteria and safeguards for the treatment of peace and security in TOSSD that the TOSSD Task Force adopted in June 2019 based on the recommendations of the pilot. It also presents some estimates on expenditures in support of peace and security gathered in the course of the pilot and TOSSD Data Survey.

Part II provides some background on the concept of TOSSD, on the development-security nexus, and on the political context around the adoption of SDG 16. It also describes the objective and methodology of this thematic pilot study.

Part III contains a detailed presentation of the pilot study's results, i.e. a summary of the expert consultations conducted and the recommendations that emerged on how to treat peace and security expenditures in TOSSD. It starts with some proposed general principles and safeguards and then addresses individually the main components of peace and security.

Part IV looks at peace and security expenditures from a provider's perspective, France, and presents preliminary figures on its TOSSD in this area.

Part V provides a light assessment of the capacity of the organisations / countries met during the pilot to provide TOSSD data on peace and security, and includes a focus on Australia's work to adjust its reporting processes accordingly. 


\section{Part I. Main findings and eligibility criteria for the treatment of peace and security in TOSSD}

Part I summarises the principal findings of the pilot study, as well as the eligibility criteria and safeguards for the treatment of peace and security in TOSSD that the TOSSD Task Force adopted in June 2019 based on the recommendations of the pilot. It also presents some estimates on expenditures in support of peace and security gathered in the course of the pilot and the TOSSD Data Survey. 


\section{Main findings}

- The inclusion of SDG 16 "Promote peaceful and inclusive societies for sustainable development, provide access to justice for all and build effective, accountable and inclusive institutions at all levels" in the 2030 Agenda on Sustainable Development has been successful in reducing, to a significant extent, the traditional dichotomy between security and development cooperation. Many institutions specialised in security co-operation, both at the multilateral (e.g. INTERPOL) and bilateral levels (the Security and Defence Cooperation Directorate of the French Ministry for Europe and Foreign Affairs), have an explicit policy of aligning their activities with the SDGs and supported including them in TOSSD. However, purely operational/tactical military support is still clearly distinct from the SDGs, e.g. support to the fighting capabilities of armed forces.

- In many low-income countries, security expenditures are not integrated in the regular budget cycle and external assistance is often provided off-budget, leading to recurrent issues of transparency and data integrity on this type of expenditures.

Capturing external security assistance in TOSSD provides a great opportunity for opening this "black box" to support efficient dialogue between development and security officials and evidence-based decisions on allocation of expenditures.

- Although SDG 16 is embedded in the 2030 Agenda, there are still unfinished discussions among experts on what types of peace and security activities can be considered as contributing to sustainable development. The adoption of SDG 16 was the result of long and difficult negotiations, due to concerns over potential negative effects of including peace, governance and justice dimensions within the SDGs. Some of these concerns remain today (interference in domestic affairs; "securitisation" of the development agenda and corresponding budget). African countries were instrumental in the final adoption of SDG 16, including issues related to peace and security.

- The usefulness of tracking peace and security expenditures in TOSSD and thus providing more transparency on expenditures in this field therefore needs to be balanced with the risk of including in TOSSD activities that, according to a number of experts, carry significant risks of undermining the SDGs. The TOSSD Task Force should follow a cautious approach and adopt mindful language about accounting support for SDG 16 in TOSSD (but not attempt to renegotiate the meaning of SDG 16). To the extent possible, the reporting instructions should take as reference international agreements with broad adherence and that are already linked to sustainable development:

- According to the UN, UN peacekeeping "remains a unique instrument for global peace and security". The view that peacekeeping contributes to SDG 16 was largely supported during the pilot, by both host countries and provider countries. They saw peacekeeping as necessary in contexts where conflict and insecurity are the first obstacles to sustainable development. However, Civil Society Organisations (CSOs) and a number of researchers, while acknowledging the contribution of peacekeeping to the maintenance of peace 
as a global public good, have raised serious concerns over including such expenditures in TOSSD given the use of the funds for combating and for support to state actors implicated in grave human rights abuses. The recommendation emerging from the pilot is to include in TOSSD only those peacekeeping operations that follow UN peacekeeping basic principles consent of the parties, impartiality, non-use of force except in self-defence and defence of the mandate. Expenditures for peacekeeping operations should be recorded as contributions to international/regional public goods (TOSSD Pillar II) to reflect that the operations, even if located in specific countries, seek to address a threat to international peace and security, and hence a global challenge.

- Disarmament is the area where discussions have been the most consensual, and it was generally considered eligible to TOSSD, including activities conducted in the context of Disarmament, Demobilisation and Rehabilitation (DDR), Small Arms and Light Weapons (SALW) control, removal of land mines and explosive remnants of war but also the reduction and elimination of biological, chemical and nuclear weapons.

- Activities combating terrorism and organised crime logically fit under SDG 16 targets which call to "significantly reduce all forms of violence and related death rates everywhere", to combat "all forms of organised crime", or "to prevent violence and combat terrorism and crime". International police cooperation (e.g. INTERPOL) was generally seen as supporting sustainable development. However, a number of stakeholders have raised serious concerns about including these activities in TOSSD, as they carry significant risks of undermining sustainable development (prevalence of repressive approaches to counter-terrorism and counter narcotics, lack of consensus on what constitutes a terrorist organisation). Still, the TOSSD eligibility of activities aimed at combating terrorism and organised crime can be guided by two international documents that are based on global consensus, have clear linkages with sustainable development, and identify specific areas of intervention: the UN Global Counter Terrorism Strategy (GCTS) and the UN Convention against Transnational Organised Crime (UNTOC) with its three supplementary Protocols - on Trafficking in Persons, Smuggling of Migrants and Trafficking of Firearms.

- Most stakeholders consulted during the pilot advocated for limiting the types of military assistance covered in TOSSD because providers of military assistance generally aim to achieve their own foreign policy objectives and advance certain security and political interests rather than promote global peace and security. By contrast, supporting security sector reform by building the capacity of partner countries' armed forces to improve civilian oversight was considered contributing to sustainable development and eligible to TOSSD. Training of partner countries' military in delivering any activity for the benefit of civilians that has a development impact, and delivery of humanitarian assistance by the military were also considered as contributing to sustainable development.

- The international tribunals and the International Criminal Court prosecute crimes seen as universally harmful to humanity, and since the motive for their establishment is to promote universal human rights, they directly contribute to 
the Agenda 2030 and should be counted under TOSSD. As for peacekeeping operations, the tribunals and other related activities are however not considered to have immediate developmental impact in the countries where they are located, but promote a global public good. The related expenditures should therefore be included in TOSSD Pillar II (contributions to international/regional public goods).

- The TOSSD reporting instructions should aim at mitigating the risk of including activities that undermine the SDGs. The TOSSD Task Force agreed on several principles and safeguards to address the concerns raised:

- The provision of lethal equipment and kinetic activities is excluded from TOSSD, given the high risk associated with this type of support (with the exception of peacekeeping operations).

- SDGs are indivisible and contributions to one target (e.g. combating crime) should not be a priori detrimental to the implementation of other targets (e.g. promotion of the rule of law or accountable and transparent institutions).

- Activities in the area of peace and security reported as TOSSD should comply with international human rights law, refugee law, international humanitarian law and the Oslo Guidelines.

- Activities should be reported with sufficiently detailed descriptions to allow scrutiny.

$\circ$ The TOSSD governance body should undertake regular reviews of peace and security activities reported in TOSSD in order to examine their alignment with the 2030 Agenda and propose revisions of the eligibility criteria if needed.

- The pilot highlighted interest by several bilateral providers and multilateral organisations for reporting their activities in TOSSD. Many bilateral providers that already report their ODA activities to the OECD were able to identify, and include in their response to the TOSSD Data Survey, additional activities in the field of peace and security that support sustainable development. Several multilateral organisations (INTERPOL, UNODC, UNOCT) that have never reported to any international development finance statistical system expressed interest in reporting their activities to TOSSD, as this would increase visibility of their work and contribution to SDGs. The pilot gave the Secretariat the opportunity to initiate a dialogue with multilateral organisations on this topic.

- TOSSD expenditures for peace and security amounted to USD 16 billion in 2017, based on first estimates gathered in the course of the pilot and the TOSSD Data Survey. In the case of France, the order of magnitude is USD 1 billion. 


\section{Eligibility criteria for the treatment of peace and security in TOSSD}

The recommendations that emerged from this pilot study (see Part III) were shared with the TOSSD Task Force at its meeting in June 2019 (Bejraoui and Gaveau, 2019 ${ }_{[1]}$ ). On the basis of the discussion, the principles, safeguards and eligibility requirements were adjusted with a focus on their verifiability and applicability from a statistical perspective and to make them clearer and consistent with each other.

Regarding the principle of "indivisibility of the SDGs", while the Task Force agreed that support to peace and security should not have a detrimental impact on other SDG targets (e.g. promotion of the rule of law), it was decided to replace the initial wording, "indivisibility of the SDGs", by "commitment to do no harm". The Task Force also stated that the "do no harm" principle can only be based on intent, meaning that the assessment of the potential detrimental impact can only be made ex ante.

For safeguards not easily verifiable at the activity level, e.g. compliance with international conventions and protocols or focus on development outcomes, reporters will make the verification at policy level.

Similarly, the Task Force, while reaffirming that local ownership was key for sustainable development, in line with the recommendations arising from the pilot, recognised that, at this stage, there was no systematic mechanism at the disposal of reporters to check the application of this principle at activity level. Therefore, ownership was finally not retained as an eligibility criterion as such, but formulated as a reminder of the need to comply with development effectiveness principles. These principles do include local ownership, and are already mentioned in the Preamble of the TOSSD Reporting Instructions.

As for the principle of "no crowding out of development budgets", the Task Force opted for the following rewording: "the eligibility of peace and security activities in TOSSD has no impact on the rules governing eligibility to be reported as ODA." TOSSD aims at providing more transparency on all types of resources that contribute to the SDGs in a unified system; it is complementary to ODA and will not by any means replace ODA as a measure of donor effort. ${ }^{1}$

The Task Force agreed to the exclusion of lethal equipment and kinetic activities, but noted the exception in the context of peacekeeping operations which allow the use of force as last resort.

The Task Force welcomed the proposal for a review mechanism, and suggested the TOSSD governance body should be in charge of this review, in order to examine the alignment of peace and security activities reported in TOSSD with the 2030 Agenda and propose revisions of the eligibility criteria if needed.

The final text adopted by the Task Force was included in the Reporting Instructions as reproduced below.

\footnotetext{
${ }^{1}$ See Annex G. of the TOSSD Reporting Instructions for a description of the main differences between the measures of TOSSD and ODA.
} 


\section{Guidance on the eligibility of Peace and Security in TOSSD}

\section{Text inserted in the TOSSD Reporting Instructions, Annex E}

General principles and safeguards
Commitment to do no harm: Activities included in TOSSD should be based on the "do no harm"
principle, meaning that both the intended and unintended consequences of interventions should be taken
into account in the activity design with the aim of ensuring "no harm" to populations. In particular,
contributions to one target (e.g. combating crime) should not be a priori detrimental to the
implementation of other targets (e.g. promotion of the rule of law or accountable and transparent
institutions).
Transparency: Activities should be reported with sufficiently detailed descriptions to allow scrutiny,
while maintaining some degree of confidentiality in situations where personal safety is plausibly
endangered.
Exclusion of lethal equipment: The provision of lethal equipment and support for or participation in
kinetic activities are not eligible to TOSSD, with the exception of peacekeeping operations.
Compliance with international conventions and protocols: The presumption is that activities in the
area of peace and security reported as TOSSD comply with international human rights law, refugee law,
international humanitarian law and the Oslo guidelines.
Compliance with development effectiveness principles: As emphasised in the Preamble, the default
assumption is that all support captured in TOSSD complies with development effectiveness principles,
in particular ownership of sustainable development priorities by recipient countries and focus on results.
It is also assumed that the activity is consistent with anti-corruption conventions and practices.
The eligibility of peace and security activities in TOSSD has no impact on the rules governing
eligibility to be reported as ODA.
Review mechanism: The TOSSD governance body will undertake regular reviews of peace and security
activities reported in TOSSD in order to examine their alignment with the 2030 Agenda and propose
revisions of the eligibility criteria if needed.

\section{Peacekeeping operations}

UN peacekeeping operations and other peacekeeping operations mandated by a UNSC resolution are eligible for TOSSD. These operations follow three basic principles:

- Consent of the parties: United Nations peacekeeping operations are deployed with the consent of the main parties to the conflict. This requires a commitment by the parties to a political process and their acceptance of a peacekeeping operation mandated to support that process.

- Impartiality: United Nations peacekeeping operations must implement their mandate without favour or prejudice to any party. Impartiality is crucial to maintaining the consent and co-operation of the main parties. Impartiality may be seen as playing a fundamental function in drawing the limits to the use of force and its purpose. Impartiality does not prohibit peacekeepers from using military force, but links and limits the use of force to a political process and the search for a political solution. The logic differs for counterterrorism which requires the identification of an enemy. 
- Non-use of force except in self-defence and defence of the mandate: A United Nations peacekeeping operation only uses force as a measure of last resort, when other methods of persuasion have been exhausted, and an operation must always exercise restraint when doing so. The ultimate aim of the use of force is to influence and deter spoilers working against the peace process or seeking to harm civilians; and not to seek their military defeat.

For other peacekeeping operations mandated by non-military regional organisations, a justification should be provided that the mandate is focused on the protection of civilians, not on defeating an enemy. Operations should support the creation of conditions for lasting peace, and not have an explicitly belligerent role and approach. They should comply with the three basic principles of UN operations listed above.

Expenditures related to peacekeeping operations should be recorded in Pillar II, to reflect that the operations, even if located in specific countries, seek to address a threat to international peace and security, and hence a global challenge.

\section{Disarmament activities}

Disarmament activities are generally eligible to TOSSD, including activities conducted in the context of Disarmament, Demobilisation and Rehabilitation (DDR), Small Arms and Light Weapons (SALW) control, removal of land mines and explosive remnants of war and reduction and elimination of biological, chemical and nuclear weapons.

\section{Law enforcement activities, including the fight against organised crime and terrorism}

To be eligible for inclusion in TOSSD, the support to law enforcement agencies to combat organised crime should be guided by the United Nations Convention against Transnational Organised Crime and the three supplementary Protocols on Trafficking in Persons, Smuggling of Migrants and Trafficking of Firearms.

Similarly, to be eligible for inclusion in TOSSD, the support to law enforcement agencies to prevent and combat terrorism should be guided by the United Nations Global CounterTerrorism Strategy.

\section{Engagement with partner countries' military}

Eligible activities include: i) capacity building of partner countries' armed forces to make them credible, accountable and managed under democratic control in an ethically-balanced and self-sustainable way; ii) training of partner countries' military in delivering any activity that has a development impact, for the benefit of civilians; and iii) delivery of humanitarian assistance by the military.

Any other type of engagement with the military is excluded from TOSSD.

\section{International tribunals}

Activities of international tribunals and related organs are eligible to TOSSD. These activities should be reported in Pillar II, even when related to a tribunal/organ prosecuting crimes perpetrated in specific countries. 


\section{The volume of TOSSD flows for peace and security}

This section presents first estimates of TOSSD expenditures in the field of peace and security gathered in the course of the pilot and the TOSSD Data Survey conducted in February-June 2019.

For the purpose of this pilot, "peace and security" refers to security system management and reform, peacebuilding, conflict prevention and resolution, peacekeeping, preventing and countering violent extremism, and other activities involving the military or the criminal justice system. It is therefore a subset of SDG16 which also includes topics of general governance (participatory governance, legal identity etc.). TOSSD expenditures for peace and security amounted to USD 16 billion in 2017, based on first estimates gathered in the course of the pilot and the TOSSD Data Survey.

\section{Table 3.1. First estimates of TOSSD expenditures in the field of peace and security}

2017, USD million

\begin{tabular}{|c|c|c|}
\hline & $\begin{array}{l}\text { Cross-border } \\
\text { flows } \\
\text { Pillar I }\end{array}$ & $\begin{array}{c}\text { Global and regional } \\
\text { expenditures } \\
\text { Pillar II }\end{array}$ \\
\hline \multicolumn{3}{|l|}{ Peace operations } \\
\hline UN Peacekeeping & & 4777 \\
\hline Other peacekeeping & & 1118 \\
\hline Peace-building, conflict prevention and resolution (purpose code 15220) & 1769 & 1395 \\
\hline $\begin{array}{l}\text { Security and Co-operation (Organisation for Security and Co-operation } \\
\text { in Europe) }\end{array}$ & 72 & 91 \\
\hline \multicolumn{3}{|l|}{ Disarmament } \\
\hline Reintegration and SALW control (purpose code 15240) & 51 & 20 \\
\hline $\begin{array}{l}\text { Removal of land mines and explosive remnants of war (purpose code } \\
\text { 15250) }\end{array}$ & 274 & 53 \\
\hline Child soldiers (prevention and demobilisation) (purpose code 15250) & 17 & 3 \\
\hline $\begin{array}{l}\text { Disarmament (UN Office for Disarmament Affairs, voluntary } \\
\text { contributions) }\end{array}$ & & 20 \\
\hline Nuclear non-proliferation (International Atomic Energy Agency) & & 451 \\
\hline $\begin{array}{l}\text { Chemical weapons (Organisation for the Prohibition of Chemical } \\
\text { Weapons) }\end{array}$ & & 83 \\
\hline \multicolumn{3}{|l|}{$\begin{array}{l}\text { Law enforcement, including the fight against terrorism and } \\
\text { organised crime }\end{array}$} \\
\hline Anti-corruption organisations and institutions (purpose code 15113) & 503 & 133 \\
\hline Legal and judicial development (purpose code 15130) & 2263 & 466 \\
\hline Narcotics control (purpose code 16061) & 56 & 31 \\
\hline International police co-operation (INTERPOL) & & 140 \\
\hline $\begin{array}{l}\text { Counter-terrorism (UN Office of Counter-Terrorism - voluntary } \\
\text { contributions) }\end{array}$ & & 42 \\
\hline $\begin{array}{l}\text { Fight against drugs and crime (UN Office on Drugs and Crime, voluntary } \\
\text { contributions) }\end{array}$ & 265 & \\
\hline \multicolumn{3}{|l|}{ Engagement with the military } \\
\hline Security system management and reform (purpose code 15210) & 908 & 781 \\
\hline \multicolumn{3}{|l|}{ International tribunals } \\
\hline International Criminal Court & & 163 \\
\hline TOSSD, estimate & 6178 & 9767 \\
\hline
\end{tabular}

Source: Pilot study (international organisations' budgets indicated in boxes in Part III) and TOSSD Data Survey (amounts allocated by purpose code). 
Part II. Information on pilot study and general background on the link between peace and security and sustainable development

Part II provides some background on the concept of TOSSD, on the development-security nexus, and on the political context around the adoption of SDG 16. It also describes the objective and methodology of this thematic pilot study. 


\section{Context and objectives of the peace and security pilot study}

\section{The concept of TOSSD}

Today, many developing countries are becoming less reliant on official development assistance (ODA) and are turning towards other types of official support, including nonconcessional resources and private capital, usually in co-financing arrangements with public finance. Moreover, with the increasing number of actors, a transparent and inclusive measurement framework is needed to measure total officially supported flows of external resources that support sustainable development.

The Addis Ababa Action Agenda (AAAA) called for the international community to confront the problem of financing and of creating a suitable environment for sustainable development at all levels, recognising the continued special role of official development finance and, at the same time, the need to mobilise other resources to support country development, within an inclusive and transparent consultative process.

Since the Addis Ababa Conference, the OECD has been working in consultation with the international community to develop a new measurement framework for the Sustainable Development Goals (SDGs) era called total official support for sustainable development (TOSSD). The TOSSD framework aims to provide a comprehensive picture of external official support for sustainable development and flows mobilised through official interventions, thereby facilitating a common international reporting standard for all providers of development co-operation, including emerging economies.

TOSSD is expressly designed to track resources invested to achieve sustainable development and will encompass all financing provided by official bilateral and multilateral institutions, regardless of the level of concessionality involved or instrument used. It includes both concessional and non-concessional financing provided through various instruments, e.g. grants, loans, equity and mezzanine finance, among others. It also aims to cover activities that promote and enable sustainable development, including contributions to global public goods that are relevant for development. It aims to create appropriate incentives for using international public finance and risk mitigation instruments to mobilise additional resources for development.

The TOSSD measurement framework ${ }^{2}$ is composed of two pillars tracking officially supported (i) cross-border or external flows to developing countries and (ii) finance for promoting development enablers and addressing global challenges at regional and global levels.

In the first semester of 2017, an International Task Force ${ }^{3}$ was established to carry out the technical work required to operationalise TOSSD and ensure it conforms to international statistical standards.

\footnotetext{
2 For further information on TOSSD, see: http://www.oecd.org/dac/financing-sustainabledevelopment/tossd.htm.

${ }^{3}$ For further information on the TOSSD Task Force, see: http://www.oecd.org/dac/financingsustainable-development/development-finance-standards/tossd-task-force.htm.
} 


\section{Why a pilot study on peace and security?}

In the 2030 Agenda for Sustainable Development, nations have indicated that they "are determined to foster peaceful, just and inclusive societies which are free from fear and violence. There can be no sustainable development without peace and no peace without sustainable development." In line with this ambition, a sustainable development goal has been established to "Promote peaceful and inclusive societies for sustainable development, provide access to justice for all and build effective, accountable and inclusive institutions at all levels" (SDG 16 and twelve related targets, see Annex A).

The TOSSD statistical measure includes all officially-supported resource flows to promote sustainable development in developing countries and to support development enablers and/or address global challenges at regional or global levels. Sustainable development in the TOSSD context being inherently linked to the SDGs as agreed in the 2030 Agenda, peace and security-related activities within the scope of SDG 16 could be included in TOSSD.

A first discussion at the 4th meeting of the TOSSD Task Force (Benn and Gaveau, 2018 ${ }_{[2]}$ ) (TOSSD Task Force, 2018 $8_{[3]}$ ) supported this proposal, recommending however a cautious approach, concrete eligibility criteria and potential safeguards to be developed in collaboration with experts.

On this basis, it was decided to carry out a pilot study to explore the relevance of including various SDG 16-related peace and security expenditures in the TOSSD framework, as "officially-supported resource flows" that either "promote sustainable development in developing countries" and/or that support peace and security as a "development enabler" and/or address security as a "global challenge at regional or global levels".

\section{Pilot study objectives and methodology}

The pilot study had four objectives (Gaveau, Bejraoui and Benn, 2019[4]]):

- Explore the scope of TOSSD in the field of peace and security and provide inputs for an informed Task Force discussion on:

- Eligibility criteria: the boundaries of TOSSD in the field of peace and security, i.e. the types of activities that could be included in TOSSD. The proposed eligibility criteria need to be straightforward to apply and avoid any ambiguity.

○ Potential safeguards to include in TOSSD.

- Delineation between TOSSD pillar I and II for peace and security expenditures.

- Test the statistical methodology of TOSSD, in particular pillar II.

- Provide estimates of TOSSD flows for peace and security: volume of funds provided for activities carried out either locally, in TOSSD-eligible countries (pillar I), or at a regional/global level (pillar II).

- Carry out a light assessment of the capacity of the organisations / countries met during the pilot to provide TOSSD data on peace and security.

The pilot study methodology consisted of three phases: (a) a desk review of existing documentation and statistics; (b) broad consultations with officials and experts involved in peace and security and sustainable development issues; and (c) the final report of the study. 
a) Desk review: The TOSSD Secretariat conducted an analysis of key documentation related to the security/development nexus, SDG 16 and to the financing aspects. The desk review also allowed the identification and study of relevant documents for the countries/organisations visited throughout the pilot (in relation to the budgets, policies, strategies, development co-operation programmes and interventions, engagement in security sector, engagement in international/regional/bilateral peacekeeping operations).

b) Consultation and interviews with officials and experts involved in peace and security and sustainable development issues ${ }^{4}$ :

- Expert workshop on 5 February 2019 in Paris (TOSSD Task Force Secretariat, $\left.2019_{[5]}\right)^{5}$

- Written questionnaire sent to the International Network on Conflict and Fragility (INCAF)

- In-depth consultation with a provider country (France)

- Consultation with recipient countries, CSOs and researchers

- Visit to selected international organisations active in the field of peace and security, mainly during two missions in Vienna and New York (March 2019)

c) The final report, which is the present document. An interim report was produced in June 2019, in the form of recommendations to the TOSSD Task Force on the treatment of contributions to peace and security in the TOSSD framework (Bejraoui and Gaveau, $\left.2019_{[1]}\right)$.

\footnotetext{
${ }^{4}$ See Annex B for the list of topics and questions that were discussed and Annex $\mathrm{C}$ for a full list of experts and institutions consulted during the pilot study.

${ }^{5}$ See Annex $\mathrm{C}$ for the list of participants. The summary of discussions can be found at: http://www.oecd.org/dac/financing-sustainable-development/development-financestandards/TOSSD $\% 20 \% 20$ peace $\% 20$ and $\% 20$ security $\% 20$ \%20summary $\% 20$ expert $\% 20$ meeting.pdf
} 


\section{General background on peace and security and sustainable development}

\section{The development-security nexus}

Peace and security is considered an international public good because the negative effects of wars, conflicts and other forms of violence can spread far beyond their zone of occurrence. Peace and security is also a necessary precondition for providing international public goods in other areas (International Task Force on Global Public Good, 2006 $[6]$ ). The pursuit of international peace is central to the UN's mandate as spelled out in the UN Charter in 1945. This is reflected in the UN structure which includes departments dedicated to peace. ${ }^{6}$ With its recent peace and security reform, the UN is seeking a more holistic approach to peace, security and development.

From the desk review, it is clear that some stakeholders see the global reach provided by the SDGs as a huge opportunity to make peace and security issues a core feature in development efforts. Global security challenges are generally seen as critical components to any global sustainable development strategy and there should be collaboration with the military and the global security establishments around the world to achieve SDG 16. The SDG 16 is also seen as providing an opportunity to bridge the divide between security and development actors, working simultaneously toward ending poverty, while mitigating the negative consequences from conflict and insecurity (Bergenas and Mahoney, 2016 $\left.6_{[7]}\right)$.

A number of developing countries support this view. For example, the Africa Leadership Forum, which initiated the Conference on Security, Stability, Development and Cooperation in Africa (CSSDCA) in 1990, recognises "the affinity between security, stability, development and cooperation", posits that "there can be no stability without security" and states that "the link between security and development as a precondition for the sustainable transformation of society is often neglected and in fact has neither been recognised nor accorded the required level of consideration and priority in Africa" (Aderinwale, 2006 $[8]$ ).

Although international peace is recognised as an international public good, and the peace and development nexus is largely acknowledged (development could not be possible without peace and security, and vice versa), there is no consensus on what specific types of peace and security activities can be considered as covered by the SDGs and there are still ongoing discussions on how to articulate development and security interventions to achieve SDG 16. For example, the Global Initiative against Transnational and Organised Crime hosted several discussions aimed at understanding the link between organised crime and sustainable development, e.g. the "Development Dialogue" series which seek "to strengthen and align policy and programmatic responses by the development community to the challenge of organised crime by providing a space for new and multidisciplinary thinking"7, or the initiative on organised crime and the SDGs ${ }^{8}$. The Pathfinders for

\footnotetext{
${ }^{6}$ The Departments of Political Affairs and Peacekeeping Operations, recently reformed into the Department of Political and Peacebuilding Affairs and Department of Peace Operations.

${ }^{7}$ https://globalinitiative.net/initiatives/development-dialogue/

${ }^{8}$ https://globalinitiative.net/initiatives/oc-and-the-sdgs/
} 
Peaceful, Just and Inclusive Societies ${ }^{9}$, a multi-stakeholder partnership that brings together UN member states, international organisations, civil society and the private sector, seeks to understand the challenges posed by the SDG targets for peace, justice and inclusion in order to accelerate their delivery. The Pathfinders emphasise that SDG 16 should not be seen in isolation and have identified a total of 36 targets (referred to as "SDG 16+ targets") directly measuring an aspect of peace, inclusion, or access to justice, with only a third of these targets included in SDG 16 (Pathfinders, 2017 ${ }_{[8]}$ ).

\section{The usefulness of tracking peace and security expenditures in TOSSD}

"Deciphering the nexus between security and development has become one of today's most pressing challenges." argues a joint team of World Bank and UN experts in their publication on security and justice sector public expenditure reviews (Harborne, Dorotinsky and Bisca, 2017 ${ }_{[9]}$ ). The book shows that security budgets are often not integrated in the regular budget cycle, and that there are recurrent issues in the integrity of the data. It underlines that this black box on security expenditures is one of the main obstacles for better integrating development and security interventions in developing countries. Our interlocutors during the pilot, including one of the authors of the book, made a plea for greater transparency and better data on security assistance. They saw TOSSD as providing a great opportunity for improvements in this field, and supported a broad coverage of peace and security expenditures in the new statistical framework, so as to provide the most comprehensive picture as possible, to support efficient dialogue between development and security officials and evidence-based decisions on allocation of expenditures.

Experts from the Swedish International Peace Institute (SIPRI) also signalled that, in the field of transitional justice, there was an issue of lack of synergy with development projects. Funding was in silos, and development projects in post-conflict societies were being designed without meeting the necessities of the local population that underwent a violent conflict.

As regards multilateral organisations active in the field of peace and security, most officials met during the pilot confirmed they would find it useful to see their organisations' contributions reflected in a statistical framework such as TOSSD. Their activities are so far not available in any international statistical system on development finance or only partly ${ }^{10}$ while they contribute to the achievement of SDGs. Including them in TOSSD would clearly fill a gap and give more visibility to these organisations' work.

While acknowledging interest in more transparency, during the expert workshop held in February 2019 -"Tracking support to SDGs - the case of peace and security" (TOSSD Task Force Secretariat, 2019 $9_{[5]}$ ) - the Civil Society Organisation (CSO) community warned that in the field of peace and security, macro political issues and the impact of measurement decisions needed to be carefully thought through too (Civil Society Organisations, $\left.2019_{[10]}\right)$. They argued that military expenditures were already very high and that

\footnotetext{
${ }^{9}$ https://www.sdg16.plus/

10 The Organisation for the Security and Co-operation in Europe reports to the OECD its activities that are eligible to official development assistance (ODA). INTERPOL, the UN Department of Political and Peacebuilding Affairs, the UN Office for Disarmament Affairs, the UN Office of Counter Terrorism and the UN Office on Drugs and Crime do not report but part of the activities they implement are reported by provider countries.
} 
Governments needed no additional "incentives" or "credit" for security spending through their inclusion in a measure such as TOSSD.

The usefulness of tracking peace and security expenditures in TOSSD and providing more transparency on expenditures in this field will therefore need to be balanced with reputational risks and the danger of crowding out development budgets.

\section{The political context around the adoption and operationalisation of SDG 16}

The 2030 Agenda affirms that "there can be no sustainable development without peace and no peace without sustainable development". Through the Goal 16, which commits countries "to promote peaceful, inclusive societies for sustainable development, to provide access to justice for all and to build effective, accountable and inclusive institutions at all levels", there is an acknowledgement that political goals - including in relation to good governance and ending violent conflict - should find a place alongside the social, economic and environmental ones. In addition, Goal 16 on peace, justice and governance defines twelve specific targets, a number of which are directly related to peace and security, such as targets 16.1 ("Significantly reduce all forms of violence and related death rates everywhere"), 16.4 ("significantly reduce illicit financial and arms flows, strengthen the recovery and return of stolen assets and combat all forms of organized crime") or 16.a ("...prevent violence and combat terrorism and crime"). However, the inclusion of these aspects, which are traditionally not considered as part of the development agenda, was not straightforward.

\section{Political context around the adoption of SDG 16}

The adoption of SDG 16 was the result of long, divisive and hard negotiations. While developed countries were in favour of including these aspects in the new development agenda, a number of developing countries opposed it, in particular through the Group of 77 (Cling, Razafindrakoto and Roubaud, 2018 ${ }_{[11]}$ ). The main concerns of developing countries and some development practitioners were related to the potential negative effects of including these dimensions within the SDGs (Saferworld, 2014 ${ }_{[12]}$ ). They can be summarised as follows:

- The inclusion of a goal on peace, justice (human rights) and governance could lead to interference in domestic affairs and violation of sovereignty.

- Including issues related to peace and security could lead to "securitisation" of the development agenda. This is one of the main concerns that still emerges today from discussions with developmental actors who fear that development budgets would be used to finance "hard" security expenditures at the detriment of longer term and more sustainable peacebuilding activities.

- Some actors expressed a restrictive approach of development focused on fighting poverty or the view that development leads to peace but not vice versa (Saferworld, $\left.2014_{[12]}\right)$. The consultations carried out throughout the pilot study have also revealed that many actors still see the SDGs as traditional development. 
It was finally under the impetus of African countries that SDG 16 was adopted ${ }^{11}$. They adopted a common position - representing the views of 54 African member States - on the SDGs that supported the creation of a goal on peace and security (African Union, $2014_{[13]}$ ). Peace and security is also a "development" topic that is brought forward by African countries at the regional level. Agenda 2063, the "continent's strategic framework that aims to deliver on its goal for inclusive and sustainable development" includes "a peaceful and secure Africa" as one of its seven aspirations.

\section{SDG 16 still under debate}

Notwithstanding the inclusion of SDG 16 in the 2030 Agenda, the pilot study has shown that the question of what specific types of peace and security activities should be considered as supporting this goal remains highly divisive. The diverging views can be loosely grouped into three categories:

- The SDGs are meant to have a broad coverage of peace and security activities, including combat and military capacities.

- Security-based approaches are not sustainable and SDG 16 should be limited to developmental strategies that address conflict and violence.

- Both developmental and security-based approaches can be useful if properly implemented, but only the former can be classified in the SDG framework, as recognising hard security issues under the SDGs could lead to securitisation of the development agenda.

In short, while there is a recognition in the 2030 Agenda that sustainable development needs to look beyond the traditional approach of development centred on poverty reduction, in particular in the field of peace and security, there is no consensus on how far this process should go.

\section{Approach taken by the Secretariat in formulating the recommendations}

The negotiations on SDG 16 resulted in the adoption of open-ended language that allows the goal to be flexible and non-prescriptive. The authors have therefore strived to follow a cautious approach in drafting the recommendations arising from the pilot study, based on the guiding principles below.

- The TOSSD Task Force should adopt mindful language about accounting support for SDG 16 in TOSSD (but not attempt to renegotiate the meaning of SDG 16, as this would be beyond its mandate).

- The TOSSD reporting instructions should aim at mitigating the risk of including activities that, according to a significant number of experts interviewed, carry a high risk of undermining the SDGs. The issue therefore is to strike the right balance between the need for transparency on all resource flows that are necessary for the achievement of the SDGs and the risk to include activities that are likely to have a negative effect on the SDGs. Several safeguards are included to address the concerns raised.

\footnotetext{
11 An interview with a participant in the negotiations revealed that the adoption of SDG 17, which provides a more equal playing field to developing countries, has also facilitated the adoption of SDG 16.
} 
- To the extent possible, the reporting instructions should take as reference international agreements that have a broad (nearly universal) international support and are already linked to sustainable development. Wherever possible, the Secretariat has also relied in priority on the view of developing countries and UN advice on which types of support can be considered as contributing to sustainable development. 


\section{Part III. Treatment of peace and security expenditures in TOSSD}

Part III contains a detailed presentation of the pilot study's results, i.e. a summary of the expert consultations conducted and the recommendations that emerged on how to treat peace and security expenditures in TOSSD. It starts with some proposed general principles and safeguards and then addresses individually the main components of peace and security (peace operations, disarmament, law enforcement including the fight against terrorism and organised crime, military activities, and international tribunals).

This publication features a number of boxes, each containing excerpts from interviews carried out with various multilateral institutions. 


\section{General principles and safeguards that should apply to peace and security expenditures}

The pilot study has generally tried to address each of the main components of peace and security separately with experts of each field. However, a number of general guiding principles for including the support to the security sectors in TOSSD have emerged. They are all presented in this section alongside with the recommendations formulated by the Secretariat to the attention of the Task Force.

\section{Indivisibility of the SDGs}

Supporting the security sector can carry significant risks of undermining other SDG targets, e.g. those related to justice, rule of law or accountable institutions. A number of interviewees warned that this would go against one of the core principles of the SDGs, their indivisibility ${ }^{12}$. Although this is a general issue that is also relevant to other SDGs, many stakeholders stressed that certain types of security expenditures could endanger rather than contribute to peace, which is the final objective of SDG 16. Therefore, they stressed that contributing to achieving one target of SDG 16 (e.g. target 16.a on preventing and combating terrorism and crime) should not be considered a sufficient eligibility criterion to be included in TOSSD. There should also be assurance that activities have no adverse impacts on other targets such as $16.1,16.3,16.4,16.5,16.7$ or 16.10 (on reducing violence, improving access to justice, participatory decision-making, anti-corruption, arms proliferation and fundamental freedoms).

Acknowledging this important principle underlying the SDGs, a number of experts stressed that in order to ensure that there is no adverse impact on other targets, or at least minimise the risk of such impact, it is crucial to adopt comprehensive and integrated approaches, addressing all the aspects of SDG 16. The Geneva Centre for Security Sector Governance (DCAF) and the United Nations Office of Counter-Terrorism have in particular supported this view ${ }^{13}$. This is also central to the approach to peace and security supported and implemented by France, see Part IV chapter 13 on the safeguards applied by France and its "3 dimensions" approach.

\section{Transparency}

Several stakeholders expressed the concern that providers could include in TOSSD activities that are not legitimate for the SDGs and that this could go unnoticed if they provided no descriptions or were reported at aggregate rather than activity level. Ministries of Defence may be reluctant and cautious to increase their transparency reporting, due to the sensitivity of some of the activities undertaken and broader institutional cultures. Transparency was therefore seen as crucial in the field of peace and security, as it can play the role of a powerful filter.

12 See the Preamble of the 2030 Agenda for Sustainable Development https://sustainabledevelopment.un.org/post2015/transformingourworld.

13 Also during the expert meeting held on 4 February 2019, a number of participants, including DCAF, advised to target both the security providers and institutions in charge of supervising them. 


\section{Focus on development outcomes and evidence-based strategies}

Only resources that have a demonstrably positive sustainable development impact should be included in TOSSD. One of the lessons learnt from the consultations is that there is a growing body of evidence showing what is most likely to work in terms of reducing violence or addressing conflict (Krisch et al., 2018 ${ }_{[14]}$ ) (Abt and Winship, 2016[15]) (Weisburd et al., 2017 ${ }_{[16]}$ ). Providers should base their interventions on evidence-based strategies and careful evaluation of the context. Relying on politically expedient approaches might worsen violence, undermine the legitimacy of governments and therefore undermine sustainable development.

\section{Recipient/host country ownership}

As explained in chapter 5 above, during the negotiations around the adoption of SDGs, a number of countries expressed concerns that Goal 16 could lead to interference in domestic affairs and violation of sovereignty. To avoid such situations, host governments should have full ownership of peace and security activities undertaken in their territories. Local ownership is also key to ensure sustainability. During the expert workshop, the G7+ emphasised the importance of the host countries' perspective. Nigeria stressed that the support should be aligned with the national SDG Agenda. A number of providers, including the UN Office on Drugs and Crime (see Box 9.3), France (see Part IV, chapter 13) and the United Kingdom (in their written contribution), also stressed the necessary condition of ownership and alignment with national strategies as defined by the recipient country.

\section{Crowding out of developmental budgets}

One recurrent concern that was expressed throughout the pilot study is a possible crowding out of development budgets by security expenditures. Many stakeholders emphasised that the recognition of certain types of support to security in TOSSD should not divert funds away from poverty eradication and human development to security-related activities. In particular, development budgets should not be used to finance "hard" security issues.

\section{The issue of lethal equipment and kinetic activities}

Although several stakeholders recognised that lethal equipment and kinetic capabilities may, in some cases, be necessary to respond to threats to peace and security, it was deemed that overall these activities can carry a high risk of misuse, and as such should not be included in TOSSD (TOSSD Task Force Secretariat, summary of expert workshop, $\left.2019_{[8]}\right)$. Moreover, it would be difficult in practice to discriminate between those activities that have a positive impact and those that have a negative impact. Finally, recognising this type of support as a contribution to the SDGs, which are still seen by many as a primarily development agenda, would risk jeopardising the legitimacy and acceptance of TOSSD at the international level. France and the United Kingdom, two providers of peace and security support, recommended the exclusion of support aiming at providing or training on the use of lethal equipment.

\section{Human rights, rule of law and accountability measures}

CSOs and a number of researchers have extensively commented on the issue of compatibility of security assistance with human rights and the rule of law and have 
highlighted that supporting the security sector can carry significant risks in this regard. A number of providers, including UN agencies, the Organisation for Security and Cooperation in Europe, and France, stressed that projects should follow human rights and rule of law-based approaches, ensuring compliance with international human rights and humanitarian law and the Oslo guidelines/humanitarian principles of humanity, impartiality, neutrality and independence. While it was noted that zero risk does not exist and that policies can only aim at minimising the risk as much as possible (as for example, abuses can happen years later, when the personnel changes), providers should strive to establish concrete mechanisms to protect human rights and anti-corruption measures. An expert from SIPRI emphasised that anti-corruption measures are often underplayed in the area of security assistance.

\section{Review mechanism}

In the view of CSOs, a reliable and credible monitoring system should be put in place to determine whether the agreed safeguards are being implemented. Such a mechanism could help challenge the practice of allocating resources to military and security objectives without due regard to their long-term development impacts or regardless of actual development needs. Many emphasised that there should be a regular ex-post monitoring system to assess the sustainability of peace and security activities reported in TOSSD and possibly revise the eligibility criteria. This task could be assigned to the TOSSD governance body. The review should be transparent, open to external experts and CSOs. ${ }^{14}$

\section{Recommendations to the TOSSD Task Force on general principles for the treatment of peace and security expenditures in TOSSD (see chapter 2 for final text as approved by the TOSSD Task Force in June 2019).}

\section{a) Indivisibility of the SDGs}

The approach followed should be cautious, and the inclusion of support should be ruled out whenever there is a credible risk of negative impacts, taking account of the examples and recommendations provided in the CSO submission.

Contribution to achieving one SDG target (e.g. 16.a) is not a sufficient TOSSD eligibility criterion in the field of peace and security. There should also be assurance that activities have no adverse impacts on other targets such as $16.1,16.3,16.4,16.5,16.7$ or 16.10 (on reducing violence, improving access to justice, participatory decision-making, anticorruption, arms proliferation and fundamental freedoms).

Addressing all the aspects of the SDG 16 is therefore crucial. As emphasised during the 2019 Stockholm Forum on Peace and Development, "national security sectors that are both effective and accountable in a framework of democratic control, the rule of law and respect for human rights are core elements of achieving the good governance ambitions of SDG 16".

\section{b) Focus on development outcomes}

Only resources that have a demonstrably positive sustainable development impact should be included in TOSSD. One of the main lessons learnt from the consultations is that there

${ }^{14}$ A CSO representative will join the International TOSSD Task Force as an observer as from end 2019. 
is a growing body of evidence showing what is most likely to work in terms of reducing violence or addressing conflict. Providers should base their interventions on evidencebased strategies and careful evaluation of the context. Relying on politically expedient approaches might worsen violence, undermine the legitimacy of governments and therefore undermine sustainable development.

c) Exclude lethal equipment and support for/participation in kinetic activities Although it was recognised that countries need to have the capacities to respond to domestic security issues, given the high risk of misuse, lethal equipment or training for kinetic operations is not eligible to TOSSD. While the combat capacities are considered as necessary, they are not part and parcel of the SDG framework.

\section{d) Make transparency an eligibility requirement}

Transparency can play the role of a first powerful filter (Ministries of Defence may be reluctant and cautious to increase their transparency reporting, due to the sensitivity of some of the activities undertaken and broader institutional cultures). In particular, sufficiently detailed descriptions that will allow scrutinising the data are essential. It should also be possible to disaggregate TOSSD datasets to ensure transparency regarding which specific SDG targets assistance contributes towards.

\section{e) Concrete mechanisms to protect human rights and anti-corruption measures} must be established.

f) Respect Oslo guidelines/humanitarian principles of humanity, impartiality, neutrality and independence.

\section{g) Ensure local ownership}

Promote ownership of development by communities and ensure the alignment of interventions under national or local development plans or programmes that respond to the specific needs of these communities. Development efforts can only be sustainable if they are owned by the recipient country.

\section{h) No crowding out of developmental budgets}

The support to the security sector should not divert funds away from poverty eradication and human development to security-related activities. In particular, development budgets should not be used to finance "hard" security issues.

\section{i) Clear separate identification of peace and security-related expenditures}

Many activities in the peace and security field will fall in Pillar II given their global nature (e.g. disarmament treaties). It is also recommended to include in Pillar II the activities conducted in developing countries when they are considered to achieve peace as a regional/international public good (e.g. peacekeeping operations) rather than to directly contribute to the development of the country concerned. This should alleviate the concerns of those who believe that the strictly developmental agenda (Pillar I) should remain separate from addressing peace and security issues (Pillar II).

\section{j) Review mechanism}

Finally, at least in the early stages of collecting data on TOSSD, it might be wise to consider that the TOSSD governance body reviews the cases brought to its attention by reporters or other stakeholders. In the view of the CSOs, a reliable and credible monitoring system should be put in place to determine whether the safeguards are being implemented. Such a mechanism could help challenge the practice of allocating resources for military and security objectives without due regard to their long-term development impacts or regardless of actual development needs. 


\section{Peace operations}

At the expert workshop held in February 2019 (TOSSD Task Force Secretariat, 2019 $9_{[5]}$ ), several participants highlighted that peacekeeping laid the ground for sustainable development and was therefore relevant for inclusion in TOSSD as a development enabler addressing the global challenge of instability and war.

The United Nations was established to "save succeeding generations from the scourge of war" and one of its main purposes is to maintain international peace and security. The UN Charter gives the UN Security Council (UNSC) primary responsibility for the maintenance of international peace and security and UN peace operations are deployed on the basis of mandates from the UNSC. Peacekeeping is often presented as one of the most effective tools available to the $\mathrm{UN}$ in the promotion and maintenance of international peace and security. The contribution of peacekeeping to sustainable peace is widely acknowledged by the UN. In its 2018 report to the UN General Assembly, the Special Committee on Peacekeeping Operations (Special Committee on Peacekeeping Operations, 2018[17]) recognises "the contribution of peacekeeping operations to a comprehensive strategy for peacebuilding and sustaining peace, and notes with appreciation the contributions that peacekeepers and peacekeeping missions make to peacebuilding." The proposed UN regular budget for 2020 is presented as aligned with the $\mathrm{SDGs}^{15}$ and all related programmes and sub-programmes are presented as contributing to sustainable development and can thus be counted in $\mathrm{TOSSD}^{16}$, including the sections in relation to the maintenance of international peace and security. ${ }^{17}$

The programme for peacekeeping operations of the proposed UN regular budget comprises the Department of Peace Operations (UN DPO) which provides support to all UN peacekeeping operations and certain special political missions. For historical reasons, two peacekeeping missions are also included: the United Nations Truce Supervision Organisation (UNTSO) and the United Nations Military Observer Group in India and Pakistan (UNMOGIP). The other UN peacekeeping operations have separate budgets (See Box 7.1).

15 The budget is currently under deliberation with the General Assembly Administrative and Budgetary committee; during the budget process, Member States have indicated that the UN regular budget will indeed support Member States in the implementation of the SDGs, but should not be presented itself as aligned with the SDGs.

16 See the proposed UN regular budget: A/76/4, available from https://documents-ddsny.un.org/doc/UNDOC/GEN/N19/142/59/pdf/N1914259.pdf?OpenElement.

${ }^{17}$ I.e. Political affairs (section 3 of the budget), Disarmament (section 4), Peacekeeping operations (section 5), Legal affairs (section 8) and International drug control, crime and terrorism prevention and criminal justice (section 16). See Annex D. 


\section{Box 7.1. The UN reform process and $U N$ peacekeeping \\ As described by UN DPO during the expert workshop held in February 2019}

\section{UN reform process}

The United Nations has undertaken a reform process, which addresses aspects related to management, development and peace and security. One of the aims of the peace and security reforms is to move beyond the traditional separation between peacekeeping operations and special political missions towards a more integrated and context-driven approach, in order to achieve sustainable peace. Many of the special political missions have a mandate similar to that of peacekeeping missions, except for the presence of military components, which is specific to peacekeeping.

Institutionally, the reform has translated in the renaming of the United Nations Department of Peacekeeping Operations (DPKO) and the United Nations Department of Political Affairs (DPA), respectively into the UN Department of Peace Operations (DPO) and the UN Department of Political and Peacebuilding Affairs (DPPA). The peacebuilding support office has been integrated into the DPPA.

\section{UN peacekeeping}

While decisions about establishing, maintaining or expanding a peacekeeping operation are taken by the Security Council, the financing of UN peacekeeping operations is the collective responsibility of all UN Member States. Every Member State is legally obligated to pay its respective share towards peacekeeping. The General Assembly apportions peacekeeping expenses based on a special scale of assessments, with the five permanent members of the Security Council required to pay a larger share because of their special responsibility for the maintenance of international peace and security.

The approved budget for UN peacekeeping operations for the fiscal year 1 July 2019 - 30 June 2020 is USD 6.5 billion. (A/C.5/73/21)

This amount finances 12 of the 14 United Nations peacekeeping missions, supports logistics for the African Union Mission in Somalia (AMISOM), and provides support, technology and logistics to all peace operations through global service centres in Brindisi (Italy) and Valencia (Spain) as well as a regional service centre in Entebbe (Uganda). The remaining two peacekeeping missions, the UN Truce Supervision Organisation (UNTSO) and the UN Military Observer Group in India and Pakistan (UNMOGIP), are financed through the UN regular budget.

The UN has no military forces of its own, and Member States provide, on a voluntary basis, the military and police personnel required for each peacekeeping operation. Peacekeeping soldiers are paid by their own Governments according to their own national rank and salary scale. Countries volunteering uniformed personnel to peacekeeping operations are reimbursed by the UN at a standard rate, approved by the General Assembly. The UN also reimburses Member States for providing equipment, personnel and support services to military or police contingents. Consultations during the pilot highlighted that costs incurred by troop and/or equipment contributing countries may surpass the standard reimbursement.

The nature and size of peacekeeping missions have evolved. In addition to the traditional peacekeeping operations focused on monitoring ceasefire, building of confidence and preventive action, UN peacekeeping includes today several larger and multidimensional operations (e.g. MINUSMA, MINUSCA) that have a mandate to protect civilians and 
support institution building. These operations respond to new realities, have complex mandates, operate across vast areas (in order to protect civilians there is a need of increased mobility and effective peacekeeping intelligence), and have limited resources.

The human rights due diligence policy, training and capacity-building, and partnerships (for example with the African Union and the European Union) are central aspects of UN peacekeeping.

The UN Secretary General prompted the initiative "Action for Peacekeeping” (A4P) which was supported by more than 150 countries that endorsed the "declaration of shared commitments for peacekeeping". The key elements of the A4P agenda are described here: https://peacekeeping.un.org/sites/default/files/a4p-declaration-en.pdf.

The UN proposed regular budget document states that UN peacekeeping "remains a unique instrument for global peace and security" and it provides a narrative on the alignment of the peacekeeping operations programme with the SDG 16: "The objective is aligned with Sustainable Development Goal 16 [...]. Progress towards the attainment of the objective will help to reduce all forms of violence and to ensure responsive, inclusive, participatory and representative decision-making at all levels." Although most UN peacekeeping operations are not covered in the UN regular budget, as centralised support services to them are considered linked to SDG 16, it would seem logical to also consider the operations themselves as linked to SDGs and count them in TOSSD.

In an interview with DPO, it was highlighted that there had always been some tension between drawing funds away from development to do peace and security and focusing peace and security funds on development, and that TOSSD could be an opportunity to go beyond these tensions. The SDG 16 targets were elaborated in part to reflect the contribution of peacekeeping activities to sustainable development, including for their military components, which play a crucial role in reducing levels of violence against civilians. It was important to recognise that peacekeeping directly contributed to SDG 16, and was not only an enabler and bridge to development. However, one interlocutor thought a distinction could be made between the operations whose mandate was focused on the protection of civilians (most UN operations) and those that have the mission to defeat an enemy (e.g. AMISOM), not necessarily compatible with the SDGs.

The Peacebuilding Support Office (PBSO) provided strong evidence during the pilot that UN-mandated peacekeeping operations consistently support SDG 16 at large, but also 16.1 specifically. Literature consulted provided some evidence of the efficiency of peacekeeping operations to sustain peace as a global public good: "UN peacekeeping is clearly a costeffective way of increasing global security" (Hegre, Hultman and Nygård, 2019 ${ }_{[18]}$ ); "peacekeeping after civil wars does indeed make an important contribution to the stability of peace" (Fortna, 2004 ${ }_{[19]}$ ). See also (Untied Nations and World Bank, 2018 ${ }_{[20]}$ )which highlights the specific contribution to violence reduction by peacekeepers. However, SIPRI also noted that some UN missions had failed to protect civilians in Rwanda, former Yugoslavia, Darfur and DRC because underequipped and politically unprepared.

A further justification for counting peacekeeping in TOSSD is that, in addition to the support to peace processes, a large part of peacekeeping operations' mandates relate to the protection of civilians, the promotion and protection of human rights, support for national and international justice and support for humanitarian assistance. (E.g., the mandate of the United Nations Multidimensional Integrated Stabilization Mission in Mali - MINUSMA 
- includes the contribution to the creation of a secure environment for the safe, civilian-led delivery of humanitarian assistance, in accordance with humanitarian principles, and the voluntary return of Internally Displaced Persons (IDPs) and refugees in close co-ordination with humanitarian actors, see Box 7.2). Most of the largest UN peacekeeping missions dedicate a large percentage of their resources to protecting at-risk populations, including IDPs.

As regards the police component of UN peacekeeping, INTERPOL noted that the Report of the UNSG on the Police Division (A/74/223 (2019)) in the context of the reform underlines the Police Division's contribution to the implementation of the 2030 Agenda, including through partnership with INTERPOL, as evidenced through joint-capacity building in the Central African Republic and Haiti.

\section{Box 7.2. Example of a UN peacekeeping mission acting under Chapter VII of the UN Charter: the United Nations Multidimensional Integrated Stabilization Mission in Mali - MINUSMA}

The mandate of MINUSMA was established by the Security Council in its resolution 2100 (2013). The most recent extension of the mandate was authorised by the UNSC in its resolution 2480 (2019), by which the Council extended the mandate of the Mission until 30 June 2020. The Mission is mandated to help the Security Council achieve the overall objective of long-term peace and stability in Mali. It acts under Chapter VII ${ }^{18}$ of the UN Charter.

MINUSMA's budget amounts to USD 1149779 for the period July 2019/June 2020, and will be used to finance i) military and police personnel - USD 495313 , ii) civilian personnel -USD 184 254, and iii) operational costs - USD 470 212. See A/73/760. It provides for the deployment of 17150 staff of which more than 15000 uniformed personnel (including military contingent personnel, formed police units and UN police). Human resources are attributed by "components", derived from the Mission mandate as shown in the table below.

The overall goal of MINUSMA is the implementation of the 2015 peace and reconciliation agreement in Mali. The mandate places a strong emphasis on the political task, as will be the case also in future for other UN operations. Human rights due diligence policy is central to the mission. An important characteristic to MINUSMA is the provision of backstopping and logistical support to the G5 Sahel Joint Force, which is not financed through the UN

18 The UN Charter gives the UN Security Council primary responsibility for the maintenance of international peace and security. In fulfilling this responsibility, the Council may adopt a range of measures, including the establishment of a UN peace operation. Chapter VI deals with the "Pacific Settlement of Disputes". UN peace operations have traditionally been associated with Chapter VI. However, the Security Council does not need refer to a specific Chapter of the Charter when passing a resolution authorising the deployment of a UN peacekeeping operation and has never invoked Chapter VI. Chapter VII contains provisions related to "Action with Respect to the Peace, Breaches of the Peace and Acts of Aggression'. In recent years, the Council has adopted the practice of invoking Chapter VII of the Charter when authorising the deployment of UN peace operations into volatile post-conflict settings where the State is unable to maintain security and public order. The Security Council's invocation of Chapter VII in these situations, in addition to denoting the legal basis for its action, can also be seen as a statement of firm political resolve and a means of reminding the parties to a conflict and the wider UN membership of their obligation to give effect to Security Council decisions. 
peacekeeping account, but through a specifically designed Trust Fund. The tasks of the missions include:

- Support political and institutional reform to help achieve the peace agreement, which means security sector reform, delivering state authority, rule of law, DDR, reconciliation and justice, etc.

- Support the State authority in delivering core services, in particular in the central region, to be able to move to the next stage of peace consolidation. MINUSMA is trying to consolidate the ground so that development agencies can take over.

- Protection of civilians, including through stabilisation activities by responding to asymmetric threats. Ensuring the protection of civilians is challenging, without adequate training and intelligence, peacekeepers risk becoming victims.

Table 7.1. Human resources of MINUSMA assigned by component

Number of staff

\begin{tabular}{|c|c|c|c|c|c|}
\hline & $\begin{array}{r}\text { Military contingents } \\
\text { (incl. } 40 \text { observers) }\end{array}$ & $\begin{array}{r}\text { United } \\
\text { Nations } \\
\text { police }\end{array}$ & $\begin{array}{r}\text { Formed } \\
\text { police } \\
\text { units }\end{array}$ & Civilians & Total \\
\hline \multicolumn{6}{|c|}{ Executive direction and management } \\
\hline & - & - & - & 205 & 205 \\
\hline \multicolumn{6}{|c|}{ COMPONENTS } \\
\hline & - & - & - & 68 & 68 \\
\hline \multicolumn{6}{|c|}{ Security, protection of civilians and implementation of the defence and security measures of } \\
\hline & 13289 & 350 & 1570 & 161 & 15370 \\
\hline \multicolumn{6}{|c|}{ Promotion and protection of human rights and reconciliation } \\
\hline & - & - & - & 101 & 101 \\
\hline \multicolumn{6}{|c|}{ Return of State authority, stabilization and the rule of law in central and northern Mali } \\
\hline & - & - & - & 101 & 101 \\
\hline \multicolumn{6}{|l|}{ Support } \\
\hline & - & - & - & 1305 & 1305 \\
\hline Total & 13289 & 350 & 1570 & 1941 & 17150 \\
\hline
\end{tabular}

Interviews with representatives from Burkina Faso, Indonesia and Nigeria confirmed that peacekeeping should legitimately be covered in TOSSD as peace is a pre-requisite for development and related costs contribute to a global public good. All three countries support the inclusion of related expenditures under Pillar II.

- Burkina Faso (see the report on a pilot study on TOSSD conducted in this country, forthcoming) stated that the use of force was part of the UN mandate, and sometimes a condition for returning to peace. The peacekeeping operations should be seen as bringing benefits to the whole region, given that vulnerability factors easily cross borders and addressing these has regional externalities; this supports classifying peacekeeping operations under TOSSD pillar II.

- Indonesia, a troop contributing country (see the report on a pilot study on TOSSD conducted in this country, forthcoming), confirmed the views collected in Burkina Faso. They also supported including safeguards, as proposed below (see recommendations). After the election of Indonesia as a non-permanent member of the UN Security Council in June 2018, the Minister for Foreign Affairs of Indonesia Retno L.P. Marsudi made a speech where she highlighted the need to foster the 
linkages between sustaining peace and sustaining development, particularly the 2030 Agenda, as one priority ${ }^{19}$. Staff interviewed from the International Security and Disarmament department of the Ministry for Foreign Affairs fully supported the inclusion in TOSSD of peacekeeping operations mandated by the UN Security Council. They also thought that other peacekeeping missions should be reviewed on a case-by-case basis; they should respect the consent of the host country and not fight a war. In their view, peacekeeping expenditures should also be classified under Pillar II, consistent with the fact that the Security Council discusses issues that constitute a threat to international security, not purely domestic issues.

In addition to paying its share of the UN peacekeeping budget, Indonesia also contributes troops (approximately 3000 , expected to grow to 7000 in future years). Indonesia would support the reflection in TOSSD of this contribution (reimbursement by the UN does not cover all expenses incurred).

- For Nigeria (Delalande et al., 2019 [21]), both UN and AU mandated operations should count in TOSSD. Safeguards should accompany the inclusion of peacekeeping expenditures in TOSSD, such as the alignment of operations with the UN Development Assistance Framework, and close co-operation with the host country authorities and relevant international agencies. The use of force should be allowed only as last resort. Even if country-specific, the operations should rather count under Pillar II as the motivation of the interventions was often to avoid the spread of violence within the borders, but also to neighbouring countries; hence the impact was regional.

However, the expert workshop and subsequent bilateral consultations revealed that CSOs and a number of researchers, while acknowledging that peace was a global public good and peacekeeping interventions a necessary pre-requisite in some situations to lay the ground for future development, thought the link between peacekeeping and SDGs was too loose to admit related expenditures in TOSSD.

They recognised that some peace operations may have a positive impact on peace and development, but they have raised serious concerns on including such expenditures in TOSSD given their role in combating and their support to state actors implicated in grave human rights abuses. They claim that the use of force by such operations should be excluded from TOSSD, as well as the logistical, training, infrastructure and intelligence assistance they provide, as in many contexts this assistance contributes to war efforts that often escalate conflict rather than contributing to the search for a political resolution of conflict and addressing human security and development needs.

Taking into account the views expressed during the pilot, and following the general approach described in chapter 5, the recommendation to the Task Force is to include UN peacekeeping expenditures in TOSSD, under Pillar II. The agreed safeguards (consent of the parties, impartiality, non-use of force except in self-defence and defence of the mandate) will need to be emphasised in future presentations of TOSSD data, to dispel doubts on the legitimacy of linking peacekeeping to sustainable development. The fact that these expenditures will be reportable under Pillar II also means that they will not be reflected in TOSSD data on cross-border flows to developing countries, and solely presented as contributions to peace as an international public good, which is less subject to controversy.

\footnotetext{
19 https://www.youtube.com/watch?v=kHm-U7_hQVc
} 
Finally, although the pilot study research on peace operations focused primarily on peacekeeping, the peacebuilding, conflict prevention and resolution aspects were also touched upon. Several organisations, such as the Organisation for Security and Cooperation in Europe (OSCE) (see Box 7.3) support conflict management and conflict mediation/negotiating processes which involve non kinetic, civilian conflict management effort to prevent escalation of violent conflict, and thus contribute to sustainable development.

\section{Box 7.3. The Organization for Security and Co-operation in Europe (OSCE)}

OSCE is the largest regional security organisation with 57 participating States $(\mathrm{pS})$ in Europe, North America and Asia. It is an intergovernmental organisation, decision-making in the OSCE is by consensus of all $57 \mathrm{pS}$. OSCE's seeks to enhance security and stability in the OSCE area through promoting dialogue and co-operation. Its work is guided by the Helsinki Final Act of 1975, which established ten founding principles guiding relations between participating States as well as a "comprehensive approach to security." This approach identifies three "dimensions" of security: a) politico-military dimension; b) economic and environmental dimension; c) human dimension. See Annex E.

The OSCE works across the "conflict cycle" to prevent conflicts from arising, to engage in crisis management when needed and to facilitate lasting comprehensive political settlements of existing conflicts. It also promotes post-conflict rehabilitation and long-term peacebuilding. To that end, it works with all relevant actors, including partnering international and regional organisations, such as the United Nations.

In recent years, as the security environment has evolved, $\mathrm{pS}$ have also established mandates for OSCE to work on security challenges that are "cross-dimensional" and transnational, such as preventing and countering violent extremism and radicalisation that leads to terrorism (P/CVERLT), organised crime, trafficking in human beings, and cyber/ICT security.

To support pS, OSCE currently has 16 field missions (at the invitation of the host government), as well as three autonomous institutions focused on the OSCE's human dimension, including the Office of Democratic Institutions and Human Rights, High Commissioner on National Minorities, and the Representative on the Freedom of the Media, and its Secretariat. Recognising that security in the OSCE area is inseparably linked to that of neighbouring regions, OSCE maintains privileged relations with 11 Mediterranean and Asian Partners for Co-operation.

\section{Link between OSCE's comprehensive approach to security and SDGs}

OSCE has recognised the link between security and sustainable development since its beginnings with the signing of the Helsinki Final Act in 1975. Its comprehensive approach to security rests on the recognition that root causes of conflicts and instability may arise not only from military threats but also from economic inequalities, environmental degradation, social insecurity and violations of individual's rights and freedoms - all relevant for the achievement of the SDGs.

The 17 Sustainable Development Goals form one integrated whole. While the activities of the OSCE as a regional security organisation have a strong focus on peace, justice and stable institutions (SDG 16), its emphasis on conflict prevention as well as its work across the "conflict cycle" (including early warning and early action, crisis management, conflict 
resolution, as well as post-conflict rehabilitation and peacebuilding) often intersects with each of the goals. See https://www.osce.org/sustainable-development-goals for further descriptions). Different parts of the OSCE - field operations, autonomous institutions, and the programmatic departments at the Secretariat - directly contribute to the SDG 16 through promotion of peaceful, inclusive, and resilient societies, equal access to justice for all and building effective, accountable and inclusive institutions at all levels; this comprehensive approach also informs its work in many of the components outlined in the pilot study (conflict prevention and management, disarmament, law enforcement, engagement with the military).

Many of OSCE's activities can be viewed as enablers of the SDGs as well. Its instruments for early warning and early action or its capacities for preventive diplomacy, dialogue facilitation and mediation help to prevent violent conflict and promote the building of lasting peace and security And its mandates to work on cross-border and regional cooperation on issues ranging from transboundary water co-operation to combating human trafficking provide necessary complement to each pS's national efforts.

As a Chapter VIII regional arrangement of the UN, UN and its agencies are one of OSCE's primary partner organisation, based on a Framework for Co-operation and Co-ordination between the two institutions. The OSCE also co-operates closely with UN agencies and missions, recognising that the UN Security Council bears primary responsibility for the maintenance of international peace and security. The pS declared the OSCE to be "a regional arrangement in the sense of Chapter VIII of the Charter of the United Nations" which recognises the existence of regional arrangements or agencies for dealing with the maintenance of international peace and security provided their activities are consistent with the Purposes and Principles of the UN.

During an interview with select OSCE staff, it was suggested that TOSSD could provide a great opportunity for reflecting aspects of OSCE's support to $\mathrm{pS}$ that had been excluded from ODA so far. In particular, OSCE provides a wide range of support related to peace and security, assistance to ministries of defence and the security sector or capacity building in terms of governance, to police, border, customs and asylum/migration officials, prosecutors and judges for human rights compliant approaches to policing, address organised crime and hate crimes, counter trafficking in human beings, P/CVERLT, and cyber/ICT security, as well as issues related to gender and security. OSCE would propose that this type of assistance be TOSSD-eligible, as it does not reinforce the operational or kinetic capacities of the military. In addition, OSCE would appreciate its efforts related to regional co-operation - both amongst ODA eligible countries, and between ODA and nonODA eligible countries - on relevant topics to be TOSSD-eligible. OSCE's work in politico-military dimension, particularly through the Forum of Security Co-operation, provides many examples (See Annex E).

\section{Financing}

OSCE is funded by assessed contributions from its $57 \mathrm{pS}$ through its Unified Budget. Its budget for 2019 is EUR 138 million. In addition, extra-budgetary contributions fund activities which further support the objectives approved in the Unified Budget (for example a multi-country simulation exercise with law enforcement officials from the criminal justice system and border $\&$ asylum/migration officials on countering trafficking in human beings, and security sector reform and governance efforts). The Special Monitoring Mission in Ukraine, which monitors the implementation of the Minsk agreement, is funded through a combination of a Special Purpose Fund and extra-budgetary contributions. 
Recommendations to the TOSSD Task Force on the treatment of peacekeeping operations (see chapter 2 for final text as approved by the TOSSD Task Force in June 2019)

- Include in TOSSD UN peacekeeping operations and other peacekeeping operations mandated by a UNSC resolution. These operations follow three basic principles :

- Consent of the parties: United Nations peacekeeping operations are deployed with the consent of the main parties to the conflict. This requires a commitment by the parties to a political process and their acceptance of a peacekeeping operation mandated to support that process.

- Impartiality: United Nations peacekeeping operations must implement their mandate without favour or prejudice to any party. Impartiality is crucial to maintaining the consent and co-operation of the main parties. Impartiality may be seen as playing a fundamental function in drawing the limits to the use of force and its purpose. Impartiality does not prohibit peacekeepers from using military force, but links and limits the use of force to a political process and the search for a political solution. The logic differs for counterterrorism which requires the identification of an enemy.

- Non-use of force except in self-defence and defence of the mandate: In certain situations at risk, the Security Council has given United Nations peacekeeping operations "robust" mandates authorizing them to "use all necessary means" to deter forceful attempts to disrupt the political process, protect civilians under imminent threat of physical attack, and/or assist the national authorities in maintaining law and order. Robust peacekeeping involves the use of force at the tactical level with the authorisation of the Security Council and consent of the host nation and/or the main parties to the conflict. A United Nations peacekeeping operation should only use force as a measure of last resort, when other methods of persuasion have been exhausted, and an operation must always exercise restraint when doing so. The ultimate aim of the use of force is to influence and deter spoilers working against the peace process or seeking to harm civilians; and not to seek their military defeat.

- For other peacekeeping operations, provide justification in TOSSD reporting that the mandate is focused on the protection of civilians, not on defeating an enemy. Operations should support a peace process, and not have an explicitly belligerent role and approach. They should comply with the three basic principles of UN operations listed above.

- Expenditures related to peacekeeping operations should be recorded in Pillar II, to reflect that the operations, even if located in specific countries, seek to address a threat to international peace and security, and hence a global challenge. Treating these expenditures as a contribution to international public goods, rather than as a cross border resource flow in support of the sustainable development of specific countries should also alleviate some of the concerns regarding the risk of blurring the lines between the security and development agendas. 


\section{Disarmament}

Although arms control is the only disarmament-related aspect mentioned in the SDGs, the area of disarmament, broadly seen, was the less controversial one in terms of inclusion in TOSSD. Consultations revealed a broad agreement among development and security experts that disarmament activities do support SDG 16, with full consensus on activities related to Small Arms and Light Weapons (SALW) control, mine clearance for civilian purposes, and Disarmament, Demobilisation and Rehabilitation (DDR). These activities were considered as contributing to both human rights and development. In addition, as emphasised by the UN Office for Disarmament Affairs, they contribute to SDG 16 but also other SDGs (see Box 8.1 on UNODA). SIPRI, which tracks capacity building activities in arms transfer and SALW control ${ }^{20}$, emphasised that TOSSD could be particularly relevant if it would track South-South funding ${ }^{21}$ for activities that promote disarmament and greater arms control. More generally, SIPRI stressed the relevance, for research purposes, of identifying the actors involved in this field and the type of co-operation assistance that countries request more often.

\section{Box 8.1. The United Nations Office for Disarmament Affairs (UNODA)}

The objective of the United Nations Office for Disarmament Affairs (UNODA) is to support multilateral efforts aimed at achieving disarmament under strict and effective international control. The main areas of focus of UNODA are military expenditures, disarmament and development, arms trade, small arms, landmines, cluster munitions, Weapons of Mass Destruction (WMD), transparency and confidence-building.

\section{Link between disarmament and sustainable development}

UNODA contributes to several SDGs, most notably SDG 16, but also other Goals such as Goals 3 (health), 4 (education), 5 (gender), 8 (decent work and economic growth), and 11 (sustainable cities). In particular, UNODA has defined a number of actions to be taken for their contribution to the SDGs ${ }^{22}$. These actions are aligned with SDG targets:

- SDG Action 16.1: Protecting civilians against the urbanization of armed conflict

- $\quad$ SDG Action $16.4^{23}$ : Reducing the illicit flows of arms and ammunition

- $\quad$ SDG Action 16.6: Promoting transparency in military expenditures and arms transfers

- SDG Action 3.d: Preparing and responding to health emergencies

- SDG Action 4.7: Disarmament education

20 See the ATT-Relevant Cooperation and Assistance Activities database http://www.attassistance.org/?page $\mathrm{id}=10$.

21 The experts cited South Africa as a potential interesting case to study.

22 https://www.un.org/disarmament/sg-agenda/en/

${ }^{23}$ As the co-custodian of indicator 16.4.2, UNODA collects data on seized, found and surrendered arms directly from States through processing biennial national reports on the implementation of the UN Programme of Action on small arms and light weapons and its International Tracing Instrument (https://smallarms.un-arm.org/sustainable-development-goals). 
- SDG Action 5.2: Addressing the gendered impact of arms

- SDG Action 5.5: Ensuring the equal, full and effective participation of women

- SDG Action 8.1: Rethinking unconstrained military spending

- SDG Action 11.5: Addressing poorly-maintained stockpiles

Activities carried out by UNODA take place at the global, regional and national levels. At the global level, UNODA promotes global norms for disarmament (through the work of the United Nations General Assembly, the Disarmament Commission, the Conference on Disarmament, or the Treaty on the Non-Proliferation of Nuclear Weapons). UNODA provides also regional capacity-building through the three UN Regional Centres for Peace and Disarmament in Africa (UNREC), Asia and the Pacific (UNRCPD), and Latin America and the Caribbean (UNLIREC). Finally, programmes are also carried out at the national level, for example in Colombia where a DDR programme is implemented.

\section{Financing}

Most of the funding of UNODA originates from the UN regular budget (USD 22.9 million in 20162017), which covers staff costs, including in the regional centres, meetings of governmental experts, the UN Programme of Fellowships on Disarmament and a portion of the operational costs of the regional centres. UNODA also receives regular budget resources under Special Political Missions (SPM) in support of the 1540 Committee on the non-proliferation of all WMD (USD 6 million in 2016-2017). This covers costs related to staff, office space, equipment, communications, technical experts, and travel of staff, experts and members of the 1540 Committee.

UNODA administers also a number of Trust Funds financed by voluntary contributions (USD 7.6 million and USD 12.4 million respectively in 2016 and 2017). Most of the Trust Funds are used to finance capacity-building activities at the national and regional levels (e.g. Trust Funds for UNREC, UNLIREC and UNRCPD), but some can also support global activities such as the promotion and universalisation of standards and norms ${ }^{24}$. In particular, the United Nations Trust Facility Supporting Cooperation on Arms Regulation (UNSCAR) strives, through provision of project funds, for integration of arms control efforts in the international development agenda. All proposals, including applications for UNSCAR funds, are required to promote the 2030 Agenda for Sustainable Development. ${ }^{25}$

Finally, in accordance with Secretary-General's Disarmament Agenda ${ }^{26}$, the Saving Lives Entity (SALIENT) was launched in October 2019. This integrated, sustained funding mechanism is being established by UNODA in partnership with UNDP and in co-ordination with the Peacebuilding Support Office. SALIENT will support country-level small arms control and armed violence reduction as part of the broader development framework, and pilot activities are being planned for 2020 .

24 An example of Trust Fund that supports global activities is the Trust Fund for the UN Disarmament Information Programme, which supports greater public awareness and understanding of multilateral efforts for arms control and disarmament.

25 Since its inception in 2013, UNSCAR has funded 80 projects in the amount of $\$ 11$ million (https://www.un.org/disarmament/unscar/ ). A total of 140 States in all regions benefitted directly or indirectly through UNSCAR-funded activities. In the current 2018-2019 cycle, 4 UNSCAR projects contributed to date collection for relevant SDG indicators. For the next cycle, all 57 applications articulated tangible outputs related to Targets 5.2, 5.5, 16.A, 16.1 and 16.4, as applicable.

${ }^{26}$ Securing Our Common Future: An Agenda for Disarmament, www.un.org/disarmament/sg-agenda/en/ 
However, two types of disarmament activities were more debated: the prevention of the proliferation of Weapons of Mass Destruction (WMD) and the handing over of disarmament capacities to the military (see chapter 10 for the latter). A few experts did not agree on the inclusion in TOSSD of global activities related to nuclear non-proliferation and the prohibition of biological and chemical weapons, which they perceived as more related to "hard" security than to a development agenda.

However, most stakeholders still advocate for considering non-proliferation work as contributing to the SDGs. In the proposed UN 2020 regular budget (see section 4 of the budget), the objective "to advance disarmament and non-proliferation in all aspects of nuclear weapons and all other weapons of mass destruction and their means of delivery" is considered as contributing to the SDG $16^{27}$. In their written comments (Civil Society Organisations, 2019 $[10])$, CSOs note that "TOSSD could legitimately include support for collection, registration, marking, safe storage and destruction of weapons and ammunition, including supporting the non-proliferation of nuclear weapons, the Arms Trade Treaty or the Organisation for the Prohibition of Chemical Weapons".

During the Open Working Group on Sustainable Development Goals ${ }^{28}$, several developing countries made reference to the importance of not neglecting disarmament, including of weapons of mass destruction:

- Egypt stated: "The suggested targets reflect, in our view, a selective approach, especially that it ignored major concerns of security and stability, in our region where we belong, particularly foreign occupation, terrorism, the arms race and the proliferation of nuclear weapons."

- Nigeria declared: “... the overarching and global issues of disarmament, particularly nuclear weapons and other weapons of mass destruction should be addressed."

Finally, with regard to nuclear safety and security, the International Atomic Energy Agency recognises its contribution to the "protection of people and the environment from the harmful effects of ionizing radiation", although it does not directly link it to the SDGs (See Box 8.2).

\section{Box 8.2. The International Atomic Energy Agency (IAEA)}

For over six decades, the Agency has pursued the objective of accelerating and enlarging the "contribution of atomic energy to peace, health and prosperity throughout the world" while ensuring that assistance provided by it "is not used in such a way as to further any military purpose." Under the motto 'Atoms for Peace and Development', it continues to

27 See section 4 in the proposed UN regular budget: A/76/4, available from https://documents-ddsny.un.org/doc/UNDOC/GEN/N19/142/59/pdf/N1914259.pdf?OpenElement.

${ }^{28}$ See the Eleventh Session of the Open Working Group on Sustainable Development Goals $-10^{\text {th }}$ meeting, $\quad$ http://webtv.un.org/search/10th-meeting-open-working-group-on-sustainabledevelopment-goals-eleventh-session/3554410066001?term $=$ open $\% 20$ 
make tangible contributions in meeting emerging global challenges in order to improve health, prosperity, peace and security around the world.

Transferring nuclear technology to developing countries, working to prevent the spread of nuclear weapons, and serving as a global platform for nuclear safety and nuclear security, are the main areas of work.

Within the framework of its Statute, the Agency has maintained the flexibility to address the evolving needs of Member States and to help them achieve their national development goals.

\section{Peaceful Uses of Nuclear Technology}

The IAEA assists its Member States in using nuclear science and technology for peaceful purposes and facilitates the transfer of this technology and knowledge in a sustainable manner to Member States.

Within the context of global development, IAEA services underpin collective efforts for the peaceful use of nuclear science and technology by promoting food security and sustainable agricultural development; improving the diagnosis and treatment of diseases and nutrition; providing knowledge and expertise for science and industry; making cleaner water accessible to more people; and understanding and protecting the environment.

They are supported by specialised IAEA laboratories in Seibersdorf, Austria, and Monaco, as well as the Technical Cooperation Programme, networks and collaborations with partners. Close collaboration between the IAEA, United Nations organisations and other partners helps to maximise the impact of IAEA support towards the achievement of Member States' development priorities, including those under the SDGs.

The IAEA's Technical Cooperation serves as a major vehicle for the transfer of nuclear science and technology to all the Member States.

\section{Safety \& Security}

The IAEA provides a strong and sustainable global nuclear safety and security framework, working to protect people, society and the environment from the harmful effects of ionising radiation.

The protection of people and the environment from the harmful effects of ionising radiation is at the heart of the IAEA's work. Whether the cause is an unsafe act or a security breach, it aims at providing a strong, sustainable and visible global nuclear safety and security framework.

IAEA assistance also facilitates safe and secure transport, handling and use of radioactive materials in fuel cycle technologies, radioactive sources for energy production and other radiation related purposes. This support includes facilitating the proper and sustainable mining of essential chemical elements for nuclear energy production, effective decommissioning of nuclear facilities and management of radioactive waste and spent fuel from cradle to grave.

Behind each IAEA project, programme and service lies a foundation of safety and security, based on IAEA standards and guidelines. The IAEA provides Member States with the assistance they need when they embark on using nuclear science and technology, through review services and facilitating tailored, dedicated training and emergency preparedness exercises. Ensuring that these uses remain peaceful and are properly managed, in order to 
protect people and the environment are paramount to the IAEA's services to Member States.

\section{Non-Proliferation}

Through its safeguards system, the IAEA verifies that States are honouring their international obligations to use nuclear science and technology only for peaceful purposes.

A principal role of the IAEA is to deter the proliferation of nuclear weapons through the early detection of the diversion of nuclear material or the misuse of nuclear technology and, in the absence of such diversion or misuse, provide credible assurances that States are honouring their legal obligations to use nuclear material and technology only for peaceful purposes.

To do so, the IAEA applies various technical measures referred to as 'safeguards' to verify the correctness and the completeness of the declarations made by States about their nuclear material and activities. IAEA safeguards are an essential component of the international non-proliferation regime.

\section{Financing}

IAEA total Regular Budget for 2018 was EUR 365.9 million. Extra-budgetary expenditures in 2018 totalled EUR 84.9 million. In 2018, the target for voluntary contributions to the Agency's Technical Cooperation Fund was EUR 85.7 million, supporting projects involving 3640 expert and lecturer assignments, 6739 meeting participants and other project personnel, 3282 participants in 196 regional and interregional training courses and 1816 fellows and scientific visitors.

\section{Recommendations to the TOSSD Task Force on the treatment of disarmament (see chapter 2 for final text as approved by the TOSSD Task Force in June 2019)}

Disarmament activities are generally eligible to TOSSD, including activities conducted in the context of Disarmament, Demobilisation and Rehabilitation (DDR), Small Arms and Light Weapons (SALW) control, removal of land mines and explosive remnants of war and reduction and elimination of biological, chemical and nuclear weapons. 


\section{Law enforcement, including the fight against terrorism and organised crime}

SDG 16 targets call to "significantly reduce all forms of violence and related death rates everywhere", to combat "all forms of organised crime", or "to prevent violence and combat terrorism and crime". In order to achieve these targets, effective law enforcement is essential. During the consultations, there was a relatively broad support for including in TOSSD support to law enforcement agencies and the judicial system to increase their capacities in crime investigation and prosecution, prisons management, and legal and judicial affairs. International police co-operation was also generally considered as contributing to sustainable development and INTERPOL, the International Criminal Police Organisation, provided detailed inputs highlighting this link (see Box 9.1).

\section{Box 9.1. INTERPOL and international police co-operation}

With 194 member countries, INTERPOL is the world's largest international police organisation. The objective of INTERPOL is to facilitate international co-operation between law enforcement agencies in order to address transnational crime. INTERPOL has three main priority programmes: counter-terrorism, organised and emerging crime, and cybercrime.

\section{Link between international police co-operation and the SDGs}

For INTERPOL, the adoption of SDG 16 acknowledges the need to go beyond the traditional dichotomy between development and security actors and recognises that security is a pre-requisite to sustainable development. The Organisation considers that criminality is an obstacle to sustainable development and that international police co-operation is key to addressing it given the transnational nature of many crime-related threats (terrorism, organised crime and cybercrime). This view was also supported by many countries, including traditional donors, emerging providers (e.g. Indonesia) and recipient countries (e.g. Nigeria).

INTERPOL is of the view that its activities contribute to sustainable development and should be reflected in TOSSD. More specifically, INTERPOL emphasises its contribution to the implementation of the SDGs through two main channels:

1. Policing capabilities that support law enforcement agencies to fight and prevent transnational crime. These include a worldwide information hub (e.g. criminal databases, exchanges of criminal intelligence) and assistance in cross-border police operations that allow a better identification, detection, deterrence and disruption of terrorist, organised crime and cyber networks.

2. INTERPOL leads globally innovative approaches and plays a central role in the global security architecture. INTERPOL provides a co-operation framework for exchanges on future trends, supports research and development on police methods and tools, facilitates the creation and harmonisation of standards and practices. An example of innovation by INTERPOL is the development of seven Global Policing Goals that are all aligned with the Agenda 2030: 
- Goal 1: Counter the threat of terrorism

- Goal 2: Promote border integrity worldwide

- Goal 3: Protect vulnerable communities

- Goal 4: Secure cyberspace for people and businesses

- Goal 5: Promote global integrity

- Goal 6: Curb illicit markets

- Goal 7: Support environmental security and sustainability

In terms of safeguards, INTERPOL puts forward its neutrality and independence. Article 3 of INTERPOL's Constitution strictly forbids the Organisation "to undertake any intervention or activities of a political, military, religious or racial character." In addition, Article 36 establishes an independent oversight body, the Commission for the Control of Interpol's Files, which is responsible for monitoring compliance of data processing via Interpol's Information System, providing independent advice, and handling requests from individuals whose data are processed within Interpol's Information System. The decision of the independent and impartial body, which is composed of elected experts, are binding and final on the Organisation, thereby providing an appropriate remedy to individuals.

\section{Financing}

In 2017, INTERPOL's consolidated budget amounted to EUR 124.3 million, with EUR 54.4 million from the regular budget/statutory contributions, EUR 36.8 million from the regular budget/other contributions and EUR 33.1 million from external funding. External contributions can originate both from public and private donors and are earmarked for specific projects. They are managed separately in trust funds and special accounts.

Two areas that are mentioned in SDG 16 have been perceived by a number of interviewees as particularly problematic, combating terrorism and organised crime. While it was recognised overall that these phenomena do undermine sustainable development, the pilot revealed disagreements regarding the "sustainability" character of some of the solutions that are applied:

- For a number of interviewees, these two fields carry significant risks of undermining sustainable development. In their written submission (Civil Society Organisations, 2019 [10] $)$, CSOs note that: "given the prevalence of repressive approaches to counter-terrorism and counter narcotics, support to governments and other security actors for 'combating' (or 'countering') terrorism and other violent or organised crime through military security, intelligence and criminal justice mechanisms should not be considered as part of TOSSD". A number of experts working on peace and security and development, for example from SIPRI and the UN Peacebuilding Support Office (PBSO), expressed similar concerns. They emphasised that due to the lack of consensus on what constitutes a terrorist organisation, support in counter-terrorism could be used to repress or suppress legitimate government opponents, which would be in sharp opposition to the SDGs. They also questioned the sustainability of militarised responses to terrorism and drug trafficking, which were described as ineffective in terms of violence reduction 
and often associated with violations of human rights and the rule of law $^{29}$. Some interviewees proposed to establish a restrictive list of TOSSD-eligible countries in the area of peace and security based on their human rights and rule of law performance. However, given the universality of the SDGs, TOSSD cannot a priori discriminate between recipient countries.

- By contrast, several other researchers and officials interviewed (generally involved in security co-operation and/or in co-operation with fragile and conflict-affected states) expressed the view that the immediate threat posed by terrorism and organised crime in many fragile countries is the primary obstacle to their sustainable development. In this context, strengthening the capacities of security forces, including combat capacities, should be considered as the priority sustainable development issue as long as it respects the sovereignty of the recipient country ${ }^{30}$. The issues of human rights and the rule of law need to be addressed in parallel but should not call into question the necessity for providing operational support to fragile countries.

- The provider countries that were consulted ${ }^{31}$ advocated for an intermediary position. They emphasised the importance of better capturing and recognising the contribution of peace and security activities to sustainable development, including in areas currently not covered in international development finance statistics such as counter-narcotics and counter-terrorism, while also recommending to follow a cautious approach. They emphasised in particular the necessary conditions of ownership, human rights and rule of law based approaches, and accountability and oversight mechanisms. In terms of coverage, most providers recommended the exclusion from TOSSD of the provision of lethal equipment or trainings on the use of lethal equipment ${ }^{32}$.

- The recipient countries consulted ${ }^{33}$ emphasised that the capacity of the police to fight day-to-day crime is key for supporting its legitimacy in the eyes of the population and for sustaining peace. They underlined the importance on the one hand of strengthening the capacity of the police to interact with the population and, on the other, of appropriately equipping law enforcement personnel. International police co-operation was also recognised as an important contributor to sustainable development.

29 It was noted for example that in the case of counter-narcotics, certain types of militarised assistance and equipment that were provided to some countries in Latin America have rather undermined public security in general, by contributing to the spread of violence within the society and the misuse of weapons.

${ }^{30}$ One researcher stated that "States should be able to defend their sovereignty and protect their populations regardless of the political regime in place."

${ }^{31}$ Based on the written comments received from members of the International Network on Conflict and Fragility (INCAF) and the in-depth consultation with France.

32 The Czech Republic, France, Portugal and the United Kingdom explicitly supported this exclusion.

${ }^{33}$ Comments received from Burkina Faso and Nigeria. 
Given that the SDG development process was ultimately led and endorsed by governments, the authors have tried, based on advice from experts, to explore whether guidance could be provided by international instruments that nation states have agreed upon. In order to be legitimate and authoritative, these instruments should have linkages with sustainable development and be based on global consensus.

\section{Preventing and combating terrorism}

Through the United Nations Global Counter Terrorism Strategy (GCTS), all UN member states have agreed on a common strategic and operational framework to fight terrorism. The GCTS was adopted in 2006 and is reviewed every two years. In terms of international legal framework, although there is no internationally agreed definition of terrorism ${ }^{34}$, UN member states have agreed to definitions of terrorism acts through the 19 international legal instruments to prevent terrorist acts (e.g. the seizure of aircraft, hostage-taking or the financing of terrorism).

The United Nations Office of Counter-Terrorism (UNOCT) has confirmed that the GCTS, as well as the activities carried out by UNOCT, do clearly fall within SDG 16 (see Box 9.2). The UNOCT programme of work will help Member States make progress towards the implementation of the SDGs as reflected in the UN regular budget for $2020 .{ }^{35} 36$

The GCTS comprises of four pillars:

- Addressing the conditions conducive to the spread of terrorism;

- Preventing and combating terrorism;

- Taking measures to build state capacity to fight terrorism and to strengthen the role of the United Nations in combating terrorism; and

- Ensuring the respect of human rights and the rule of law while countering terrorism.

UNOCT confirmed that, in the context of the GCTS, combating terrorism does not cover kinetic capabilities ${ }^{37}$. On the contrary, the Strategy emphasises the critical importance of international co-operation to counter terrorism, and identifies specific measures to build

\footnotetext{
${ }^{34}$ Members agreed on the definition of a number of terrorism acts but a global definition is still lacking because countries disagree on whether some acts can be qualified as terrorism (e.g. resistance to occupation and acts committed by armed forces and nation states).

${ }^{35}$ In particular, the UNOCT objective is presented in the proposed UN budget (section 3 on political affairs) as "aligned with Sustainable Development Goal 16 [...] Progress towards the attainment of the objective will help to strengthen relevant national institutions, including through international cooperation, for building capacity at all levels, to prevent violence and combat terrorism.".

${ }^{36}$ In addition, the 2017 report on SDG implementation presented to the United Nations General Assembly by its President referenced an activity related to the GCTS as supporting SDG 16. See Annex I of "The Sustainable Development Goals: A Universal Push to Transform Our World". https://www.un.org/pga/71/wp-content/uploads/sites/40/2015/08/report-on-SDG-implementationefforts-during-the-71st-session-of-the-General-Assembly.pdf.
}

${ }^{37}$ Although countries may need kinetic capabilities to respond to terrorist acts, these are not part of the discussions around the GCTS. 
states' capacity to prevent and counter terrorism. These measures include, but are not limited to, the following:

- Facilitation of implementation of the international conventions and protocols related to the prevention and suppression of terrorism and relevant United Nations resolutions.

- Combating money laundering and financing of terrorism.

- Reform and modernisation of border management systems, facilities and institutions at the national, regional and international level.

- Assistance provided in transport security (e.g. aviation security).

- Assistance in developing an effective and rule of law-based criminal justice system $^{38}$.

In terms of safeguards, the GCTS calls on all countries to ensure that any measure they take to combat terrorism complies with their obligations under international law, "including the Charter of the United Nations and relevant international conventions and protocols, in particular human rights law, refugee law and international humanitarian law."

\section{Box 9.2. The United Nations Office of Counter-Terrorism (UNOCT)}

The United Nations Office of Counter-Terrorism (UNOCT) was established on 15 June 2017 by the UNGA resolution 71/291. It has five main functions:

a. provide leadership on the General Assembly counter-terrorism mandates entrusted to the Secretary-General from across the United Nations system;

b. enhance co-ordination and coherence across the 38 Global Counter-Terrorism Coordination Compact entities to ensure the balanced implementation of the four pillars of the UN Global Counter-Terrorism Strategy;

c. strengthen the delivery of United Nations counter-terrorism capacity-building assistance to Member States;

d. improve visibility, advocacy and resource mobilisation for United Nations counterterrorism efforts; and

e. ensure that due priority is given to counterterrorism across the United Nations system and that the important work on preventing violent extremism is firmly rooted in the Strategy.

\section{Link between counter-terrorism and sustainable development}

UNOCT, confirmed the link between the GCTS and the SDGs. UNOCT also confirmed that the totality of their programmes, projects and activities implemented by the Office contributes towards achieving objectives of the SDG framework.

The UN Counter-Terrorism Centre (UNCCT) and Special Projects and Innovation Division (SPID) are two integral parts of UNOCT responsible for delivering counter-terrorism capacity building to UN Member States. Besides, UNOCT also confirmed that its capacity

38 The criminal justice system is generally defined as including law-enforcement agencies, the judicial system (courts, tribunals, etc.) and custodial institutions (jails, prisons, etc.). 
building programmes and projects delivered in partnership with the UN Counter-Terrorism Compact entities and international organisations fall within the SDGs ${ }^{39}$.

In terms of counter-terrorism (CT) and preventing and combating violent extremism (PCVE) assistance to countries, examples of activities include PVE, based on the UN Secretary-General's Plan of Action to prevent violent extremism ${ }^{40}$, trainings of law enforcement officials on human rights and the rule of law, and capacity-building in the detection, prevention, investigation, prosecution, incarceration and rehabilitation of "individuals or groups who use terror to achieve their aims".

The Plan of Action to Prevent Violent Extremism considers and addresses violent extremism as, and when, conducive to terrorism. The Plan of Action acknowledges that violent extremism is a diverse phenomenon, without clear definition. It is neither new nor exclusive to any region, nationality or system of belief. Global and regional activities that could be eligible to TOSSD Pillar II include international co-operation and co-ordination (e.g. the work of the Global Counter Terrorism Coordination Compact) and standardsetting (e.g. development of guidelines and good practices).

The UN Global Counter-Terrorism Coordination Compact was signed on 23 February 2018 by the UN Secretary-General as an agreed framework with the heads of then $36 \mathrm{UN}$ entities plus INTERPOL and the World Customs Organisation. The aim of the Global Compact is to strengthen a common UN action approach to support Member States, at their request, in the balanced implementation of the UN Global Counter-Terrorism Strategy (GCTS) and other relevant UN resolutions and mandates, in line with international law, including international human rights, humanitarian and refugee law. The launch of the Global Compact was a major step forward in enhancing the co-ordination and coherence in the work of UN entities on preventing and countering terrorism and the underlying spread of violent extremism, while respecting existing mandates.

As of 15 November 2019, the Global Counter-Terrorism Coordination Compact comprises 42 entities, as member or observer. Global Compact entities collaborate through eight interagency Working Groups, which focus on thematic priority areas identified under the four pillars of the UN GCTS. The implementation of the Global Compact is steered by a Coordination Committee chaired by the Under-Secretary-General for Counter-Terrorism and guided by a joint programme of work for 2019-2020 adopted by the Committee in July 2019. UNOCT serves as Secretariat of the Global Compact Coordination Committee.

Regarding the safeguards, UNOCT highlighted the importance of integrated approaches focussing on the four pillars of the GCTS, including human rights. It was also confirmed that UN counter-terrorism assistance is designed to be in compliance with international

39 For examples of activities, see the UNOCT's Consolidated Multi-Year Appeal 2019-2020 (https://www.un.org/counterterrorism/ctitf/sites/www.un.org.counterterrorism.ctitf/files/UNOCT Multi-Year-Appeal_Website.pdf ) and the 2018 Annual Report of UNCCT https://www.un.org/counterterrorism/ctitf/sites/www.un.org.counterterrorism.ctitf/files/UNCCT\% 20Annual\%20Report\%202018.pdf ). See also Part V, section 16.

${ }^{40}$ In the Plan, the UN Secretary-General calls for a comprehensive approach encompassing not only essential security-based counter-terrorism measures but also systematic preventive steps to address the underlying conditions that drive individuals to radicalise and join violent extremist groups. The Plan is an appeal for concerted action by the international community. It provides more than 70 recommendations to Member States and the UN system to prevent the further spread of violent extremism. https://www.un.org/counterterrorism/ctitf/en/plan-action-prevent-violent-extremism. 
human rights and humanitarian laws and that concrete risk assessment and risk management strategies are being put in place.

In terms of countries receiving technical assistance, the UNOCT and its partners are presently focused on streamlining their portfolios and aligning their programmes and projects with technical assistance needs identified by the Counter-Terrorism Executive Directorate as a result of regional and country specific technical assessments and assessments of global emerging threats. Technical assistance by the UN is provided to a number of developing countries (countries eligible to ODA) although the UN does not have an income focus. Some projects can also directly benefit high-income countries, for example in the case of regional projects targeting the Middle East and North Africa region.

\section{Financing}

The primary funding source of UNOCT programmes and activities is the Trust Fund for Counter-Terrorism financed from voluntary contributions from Member States. The financing from the regular budget is small, with USD 1.6 million allocated to $\mathrm{UNOCT}^{41}$ in the proposed UN regular budget for 2020. The budgets of the UNOCT portfolio of programmes and projects in 2020 is estimated at USD 42 million to be financed from voluntary contributions. Since its inception, the Trust Fund has received contributions from 30 donors, the largest of which were the Kingdom of Saudi Arabia, the State of Qatar, the European Union, the Netherlands and the United States. Eight donors are middle-income countries. Among these, India is the largest donor with the contribution of USD 550,000. In 2018, two projects were also supported by the Peace and Security Fund, which is funded by China and managed by the Executive Office of the Secretary-General.

In 2019, UNOCT launched the first consolidated multi-year appeal for UN counterterrorism efforts. The Appeal, which covers projects from across the Global CounterTerrorism Coordination Compact for 2019-2020, outlined requirements submitted by 12 UN entities participating in the Appeal for a total amount of USD 193.78 million. ${ }^{42}$

\section{Preventing and combating organised crime}

The main international legal instrument for combating organised crime is the United Nations Convention against Transnational Organised Crime (UNTOC) and the three supplementary Protocols - on Trafficking in Persons, Smuggling of Migrants and Trafficking of Firearms ${ }^{43}$. The UNTOC and its Protocols are legally binding instruments

${ }^{41}$ See the proposed UN regular budget, Section 3. Political affairs, budget component A6 on Counter-Terrorism Implementation task Force. [A/76/4 (sect. 3), available from https://documentsdds-ny.un.org/doc/UNDOC/GEN/N19/142/59/pdf/N1914259.pdf?OpenElement]

42 See page 97 of UNOCT Consolidated Multi-Year Appeal 2019-2020 https://www.un.org/counterterrorism/ctitf/sites/www.un.org.counterterrorism.ctitf/files/UNOCT Multi-Year-Appeal_Website.pdf

43 The UNTOC was adopted by the UN General Assembly in 2000. 
that provide a framework for combating many forms of crime ${ }^{44}$. In terms of adherence, the Convention is nearly universal, with 189 States Parties at present.

Discussions with the United Nations Office on Drugs and Crime (UNODC), which serves as the Secretariat of the UNTOC, highlighted that sustainable development can only be possible if the root causes of vulnerability are addressed. In areas affected by conflict or permanent presence of crime, these root causes are often linked to criminal exploitation (see Box 9.3).

Several elements confirm the link between the UNTOC and sustainable development. Section 16 of the proposed UN regular budget (International drug control, crime and terrorism prevention and criminal justice) covers UNODC and its work, including in relation to the UNTOC and the three protocols. Subprogramme 1 on "Countering transnational organized crime" will support Members States in the implementation of the SDGs: "The objective is aligned with Sustainable Development Goal 5 [...] Goal 8 [...] Goal 10 [...] Goal 15 [...] Goal 16 [...] Goal 17". The UNTOC itself establishes a clear link between organised crime and sustainable development. Article 30 recognises "the negative effects of organised crime on society in general, in particular on sustainable development" and invites state parties "to enhance financial and material assistance to support the efforts of developing countries to fight transnational organised crime effectively". The importance of the UNTOC for the development agenda is also recognised in the Addis Ababa Action Agenda ${ }^{45}$. More recently, in the key recommendations formulated following the SDG 16 conference that was organised in preparation for the 2019 High-Level Political Forum on Sustainable Development, UN member states are called upon to "accelerate efforts to ratify, comply with, and implement existing international legal frameworks like the United Nations Convention against Transnational Organized Crime (UNTOC), including its three protocols, the United Nations Convention against Corruption (UNCAC) and the Firearms Protocol, with particular emphasis on sustainable development." 46

In addition to emphasising the importance of international co-operation in the fight against organised crime, the UNTOC identifies specific areas in which training and technical assistance should be provided to law enforcement personnel and for which state parties are requested to assist one another ${ }^{47}$. These include:

44 Including trafficking in cultural property, cybercrime, drug trafficking, money laundering and illicit financial flows, trafficking of wild fauna and flora and forest products, maritime piracy, illegal mining, trafficking in precious metals, crimes related to fishing, illicit trafficking in firearms, human trafficking and migrant smuggling.

45 See paragraph 112 of the Addis Ababa Action Agenda https://www.un.org/esa/ffd/wpcontent/uploads/2015/08/AAAA_Outcome.pdf

46 The conference was organised by the UN Department of Economic and Social Affairs (DESA) and the International Development Law Organization (IDLO). See the key recommendation on page 3 of the "Outcome: key messages and recommendation" https://sustainabledevelopment.un.org/content/documents/23814SDG_16_MAIN_SUMMARY_S DG_Conference_Rome_May2019.pdf

47 See Article 29 of the UNTOC on "Training and technical assistance" https://www.unodc.org/documents/middleeastandnorthafrica/organisedcrime/UNITED_NATIONS_CONVENTION_AGAINST_TRANSNATIONAL_ORGANIZED_C RIME_AND_THE_PROTOCOLS_THERETO.pdf. 
- Methods used in the prevention, detection and control of the offences covered by this Convention;

- Routes and techniques used by persons suspected of involvement in offences covered by this Convention, including in transit States, and appropriate countermeasures;

- Monitoring of the movement of contraband;

- Detection and monitoring of the movements of proceeds of crime, property, equipment or other instrumentalities and methods used for the transfer, concealment or disguise of such proceeds, property, equipment or other instrumentalities, as well as methods used in combating money-laundering and other financial crimes;

- Collection of evidence;

- Control techniques in free trade zones and free ports;

- Modern law enforcement equipment and techniques, including electronic surveillance, controlled deliveries and undercover operations;

- Methods used in combating transnational organised crime committed through the use of computers, telecommunications networks or other forms of modern technology; and

- Methods used in the protection of victims and witnesses.

\section{Box 9.3. The United Nations Office on Drugs and Crime (UNODC)}

The United Nations Office on Drugs and Crime (UNODC) is the UN entity in charge of providing leadership in the fight against illicit drugs and international crime ${ }^{48}$. UNODC serves, in particular, as the Secretariat of the United Nations Convention against Transnational Organised Crime (UNTOC) and the three supplementary Protocols on Trafficking in Persons, Smuggling of Migrants and Trafficking of Firearms. ${ }^{49}$

\section{Link between organised crime and sustainable development}

For UNODC, the objective of SDG 16 is to tackle the root causes of vulnerability, which in areas affected by conflict or permanent presence of crime, are often linked to criminal exploitation. Sustainable development will only be possible if these root causes are addressed. UNODC programmes are aligned with the national Sustainable Development Goal targets of Member States, and wherever possible, the global level Goal targets and

48 The mandates of the United Nations Office on Drugs and Crime (UNODC) are articulated around crime prevention, monitored by the Commission on Crime Prevention and Criminal Justice, and drug control, monitored by the Commission on Narcotics Drugs.

${ }^{49}$ UNODC serves also as the Secretariat of the three main international drug control conventions: the Single Convention on Narcotic Drugs of 1961 as amended by the 1972 Protocol, the Convention on Psychotropic Substances of 1971 and the United Nations Convention against Illicit Traffic in Narcotic Drugs and Psychotropic Substances of 1988. 
indicators, as well as the 2030 Agenda as a whole. The institution insisted on the importance of countries' ownership. All UNODC's projects are designed with the recipient country and aligned with its national SDG agenda.

UNODC considers all its activities as aligned with the SDGs, in particular SDG $16^{50}$. In relation to the UNTOC, UNODC is for example mandated to support the capacity of criminal justice systems to investigate and prosecute organised crimes in line with human rights standards. Another area through which UNODC contributes to SDG 16 is terrorism prevention, although this is not its core work. Examples of activities include capacity building to criminal justice systems to more effectively prevent and counter terrorism, promoting and protecting human rights and fundamental freedoms while countering terrorism, and assisting countries in the implementation of the 19 universal legal instruments against terrorism ${ }^{51}$. Finally, UNODC is also very active on cybercrime (training on dark net investigations, crimes committed against children).

In terms of global activities that could be eligible to TOSSD Pillar II, UNODC has important normative functions through its two commissions ${ }^{52}$ and produces extensive research (e.g. the World Drug Report) and statistics that are made available in the public domain.

\section{Financing}

Although UNODC benefits from the UN regular budget, most of its funding originates from voluntary contributions $(96 \%)$ provided by countries, multilateral organisations or the private sector. In 2017, total expenditures of UNODC amounted to USD 286.9 million, with 22.4 million from the UN regular budget and the rest from voluntary contributions ${ }^{53}$. The expenditures are divided between the policy making organs ( 0.8 million), the executive direction and management (3.1 million), programme support (13.8 million) and the programme of work (269.1 million). In terms of sectoral distribution, $30 \%$ of the expenditures were allocated to countering illicit drug trafficking and transnational organised crime, $27 \%$ to prevention, treatment and reintegration, and alternative development, $8 \%$ to countering corruption, $11 \%$ to justice, $10 \%$ to research, trend analysis and forensics and $6 \%$ to terrorism prevention ${ }^{54}$.

${ }^{50}$ UNODC contributes also to other SDGs, for example through preventing wildlife and forest crime (SDG 15), preventing illegal fishing activities (SDG14), or preventing HIV in prisons and drug abuse and rehabilitation (SDG 3).

${ }^{51}$ UNODC is also one of the 38 participating entities in the Counter-Terrorism International Task Force.

52 For example, the Commission on Narcotics Drugs decides on the placement of narcotic drugs and psychotropic substances under international control.

${ }^{53}$ See the 2017 annual report of UNODC https://www.unodc.org/documents/AnnualReport/AnnualReport_2017.pdf

${ }^{54}$ In addition, $4 \%$ of the expenditures were allocated to technical co-operation and field support, $2 \%$ to policy support, and $2 \%$ to the provision of support to the governing bodies and the International Narcotics Control Board. 
Recommendations to the TOSSD Task Force on the treatment of law enforcement activities, including the fight against organised crime and terrorism (see chapter 2 for final text as approved by the TOSSD Task Force in June 2019)

- The support to law enforcement agencies to combat organised crime should be guided by the United Nations Convention against Transnational Organised Crime and the three supplementary Protocols on Trafficking in Persons, Smuggling of Migrants and Trafficking of Firearms.

- The support to law enforcement agencies to prevent and combat terrorism should be guided by the United Nations Global Counter-Terrorism Strategy. 


\section{Engagement with the military}

Military support may be considered a legitimate form of foreign assistance like economic or development aid. It can help recipient countries to modernise or better equip their armed forces under the stated objective of fostering peace and stability in the country and/or region. But at the same time, providers of military aid aim to achieve their own foreign policy objectives and advance certain security and political interests.

A few voices during the pilot supported the idea of including military support in TOSSD as this would promote more transparency on comprehensive expenditures at country level (see chapter 5 , section on the usefulness of tracking peace and security in TOSSD). Some were also convinced that military support was vital in certain regions of the world, e.g. Sahel, to help the authorities of countries concerned to protect their populations and the sovereignty of their territory. In their publication "Linking security and development, a plea for the Sahel" (Guillaumont et al., 2016 $6_{[22]}$ ), experts from the Foundation for studies and Research on International Development (FERDI) describe peace in the Sahel as "a public good, the consequences of which are felt beyond the continent of Africa" and indicate that security spending in Africa is still lower than required by the situation of insecurity in the Sahel. The publication further states that "Although security in the Sahel is a global public good, the international community remains reluctant to support an increase in spending." The publication proposes some solutions to promote more spending in this field including: donors that contribute budget assistance to these countries should accept higher levels of military spending than currently; African governments should be more transparent on their security spending which could be based on military planning laws approved by the donors; the definition of official development assistance should allow more security spending. On the latter suggestion, it should be noted that TOSSD could be considered a more appropriate measure of development finance than ODA to include broader security spending, given the wider coverage of SDGs in this field.

However, the majority of stakeholders consulted during the pilot, while possibly recognising the advantages of more integrated approaches involving development and security actors, were rather strongly opposed to including in TOSSD financing or support to partner countries' military. In their view, strengthening the operational, tactical and fighting capabilities of partner countries' armed forces, through training or provision of military combating/lethal equipment, should be excluded from TOSSD. The reason is that there is no conclusive evidence that domestic military expenditure supports sustainable development and that transfer of munition and military hardware contributes to violence reduction (SDG 16.1). At the same time it was noted that these activities can carry significant risks of undermining other SDG targets and that they often aim at defending specific providers' interests rather than sustainable development. In addition, PBSO indicated in their written contribution that evidence suggests that direct military intervention by third parties in a conflict prolong conflict and increases hardship suffered by the civilian population; it should thus be excluded. Military alliances (bilateral and multilateral, e.g. NATO) may promote peace, for participating countries, but can engender arms races, and pit peace and security as a zero-sum game for non-members of military alliances; they can also be used for interventions in third countries with dubious outcomes and should be excluded from TOSSD. SIPRI then suggests the conservative and feasible approach to exclude military assistance entirely, with the exception of UN peacekeeping (see Chapter 7). 
While reinforcing the operational capacities of the military with no clear developmental purpose should not be eligible, the expert workshop in February 2019 illustrated through concrete examples that building the capacity of partner countries' armed forces to make them credible, accountable, ethically-balanced and managed under democratic control did contribute to sustainable development, so inclusion of such activities in TOSSD should be allowed. Training the military in delivering any activity that has a development impact could also be considered. SIPRI experts have not formed a unified position on the topic but have reflected on the treatment of demining. They noted that, even if demining training is for humanitarian purpose and regarded as beneficial for the civilian populations, there is a potential use of trained personnel for a military purpose. Moreover, also ex-combatants are usually trained and involved in such activities and, according to the transitional justice literature, this can pose a serious risk to the security of a post-conflict environment if transitional justice mechanisms have not been successful in their prosecution and vetting procedures. Still, they mentioned three examples of projects in the area of demining deemed non-ODA eligible in the Casebook that could be seen as TOSSD-eligible, given their relation to SDG 16.1 (by removing explosive hazards and providing education on safe behaviour). ${ }^{55}$

As for CSOs, because of the risks they pose of exacerbating conflict and undermining progress in addressing conflict drivers, military interventions and defence support programmes should not be included in TOSSD, except in some specific instances (Civil Society Organisations, $2019_{[10]}$ ). Indonesia confirmed the view that defence issues were not covered by the SDGs.

Recommendations to the TOSSD Task Force on the treatment of engagement with partner countries' military (see chapter 2 for final text as approved by the TOSSD Task Force in June 2019)

- Include capacity building of partner countries' armed forces to make them credible, accountable and managed under democratic control in an ethically-balanced and selfsustainable way.

- Include training of partner countries' military in delivering any activity that has a development impact, for the benefit of civilians.

- Exclude any other form of financing for partner countries' military (strengthening the fighting capacity of partner countries' armed forces, through training or provision of military combating/lethal equipment; military interventions - other than peacekeeping operations - and military alliances, activities that may result in civilian casualties, etc.).

${ }^{55}$ See Cases 9,12 and 16 in the Casebook at http://www.oecd.org/dac/financing-sustainabledevelopment/development-finance-standards/oda-eligibility-database/. 


\section{International tribunals}

International tribunals prosecute crimes seen as universally harmful to humanity, and since the motive for their establishment is to promote universal human rights, a number of stakeholders have highlighted their contribution to the Agenda 2030 and the relevance of counting them under TOSSD.

The international tribunals and the International Criminal Court (ICC) ${ }^{56}$ are mandated to prosecute individuals for crimes which have been defined as international, or rather supranational, such as genocide or crimes against humanity. The ICC is governed by an international treaty called the Rome Statute; it participates in a global fight to end impunity, and through international criminal justice, the Court aims to hold those responsible accountable for their crimes and to help prevent these crimes from happening again. Justice is a key prerequisite for lasting peace and international justice can contribute to long-term peace, stability and equitable development in post-conflict societies. These elements are foundational for building a future free of violence.

As for peacekeeping operations, the tribunals and other related organs such as the IIIM (International, Impartial and Independent Mechanism to assist in the investigation and prosecution of persons responsible for the most serious crimes under International Law committed in the Syrian Arab Republic since March 2011) or the Independent Investigative Mechanism for Myanmar (IIMM) are however not considered to have immediate developmental impact in the countries where they are located, but benefit to a global public good and related expenditures should therefore be included in TOSSD Pillar II.

In the course of the pilot, the topic of international tribunals was hardly discussed. Indonesia commented that they should be included on a case-by-case basis as long as there was consent of the people concerned. It was important to focus on building the capacity of local tribunals to enable nationally-driven processes, like it occurred in Timor Leste. In the UN regular budget, the IIIM and IIMM are covered under section 8 (legal affairs). The objectives of these mechanisms are to "ensure accountability for serious international crimes" and "violations of international law" and "justice, which is one of the values enshrined in the Charter of the United Nations". They will support member States in the implementation of SDGs 5 and 16. Progress towards the attainment of the objective will "help to promote the rule of law at the national and international levels and ensure equal access to justice for all". The IIIM "will also assist efforts to end abuse, exploitation, trafficking and all forms of violence against, and torture of, children".

Recommendations to the TOSSD Task Force on the treatment of international tribunals (see chapter 2 for final text as approved by the TOSSD Task Force in June 2019)

- Include the ICC, international tribunals and related organs such as the IIIM.

- Expenditures should be reported in Pillar II, even those directed to a tribunal/organ prosecuting crimes perpetrated in specific countries.

\footnotetext{
56 This section does not cover the International Court of Justice (ICJ) which has less of a direct link with peace and security. The ICJ is the judicial organ of the UN that deals with public international law (the laws of states). Unlike the ICC, the ICJ has no jurisdiction to try individuals accused of war crimes or crimes against humanity.
} 


\section{Part IV. The Perspective of France as a Provider}

A more in-depth consultation was carried out with the French authorities. The objective was to explore the contributions of France in the field of peace and security and investigate the perspective of the country on their links with the SDGs and on the boundaries and eligibility criteria of TOSSD. France submitted written comments in response to the questions that were raised during the Expert workshop held on 5 February. In addition, bilateral interviews were undertaken with representatives from:

- The French Ministry for Europe and Foreign Affairs - MEFA (the DirectorateGeneral for Globalization, Culture, Education and International Development; the Security and Defence Co-operation Directorate; the Crisis and Support Centre).

- The Ministry for the Economy and Finance.

- The French Agency for Development.

- The Ministry of Armed Forces.

The following sections are based on the written comments sent by France and the subsequent interviews. They are structured as follows:

- Perspective of France on the coverage of peace and security expenditures in TOSSD (section 12).

- Safeguards proposed by France for recording peace and security expenditures in TOSSD (section 13).

- TOSSD estimates on peace and security expenditures by France and presentation of the co-operation actors (section 14). 


\section{Perspective of France on the coverage of peace and security expenditures in TOSSD}

France proposed four general principles that should guide the eligibility rules for peace and security activities in TOSSD. These are:

1. "The purpose and impact on sustainable development of each peace and security co-operation activity prevails on the nature of providers and recipients". No activity should be a priori excluded because of the nature of the delivery agent or cooperating partners.

2. "Institutional support (through integrated, inclusive, long term co-operation and under supervision of political leadership) must be considered eligible, unlike tactical support (provided by one ministry or military force in a limited silo of expertise)." Activities aimed at improving the tactical capacities of the military should not be eligible to TOSSD. Similarly, support aiming at providing or training on the use of lethal equipment should not be eligible to TOSSD.

3. "The situation of the receiver should be taken in consideration, as in a fragile/failed state or a state in crisis, the co-operation provided for would most probably pertain to a tactical, operational domain."

4. "Safeguards are necessary to mitigate the risks inherent to each activity: ownership of the recipient country (national/ local authorities); transparency in definition and implementation; integrated approach and partnerships among various state actors; overarching frameworks explicitly taking into account the respect of human rights as well as democratic governance and rule of law principles; existing oversight and accountability mechanisms."

\section{Peacekeeping}

In the area of peacekeeping, France proposed that all peacekeeping operations mandated (or authorised) by the United Nations Security Council (UNSC) be fully eligible to TOSSD. This includes United Nations peacekeeping operations but also non-UN peacekeeping missions authorised by UNSC, such as AMISOM. France also proposed that other peacekeeping operations that are not mandated or authorised by UNSC but that have a mandate from a regional organisation (e.g. African Union or ECOWAS) be eligible on the basis of their mandate - it should follow the same principles than UN peacekeeping - and the type of activities they undertake. France provided two examples of missions that could be eligible: the African Union observers on human rights and the ECOWAS mission in Guinea Bissau that assesses the implementation of peace talks.

\section{Disarmament}

France proposes a large coverage of disarmament activities in TOSSD, including the fight against landmines, control of small arms and light weapons, prohibition of chemical weapons or nuclear proliferation. These activities can all be considered as supporting 
SDG 16 and should therefore be included in TOSSD. In addition, France proposed to include in TOSSD training activities and handover of disarmament expertise to local authorities. Support to the military in this field should not be considered a red line, as long as safeguards are established in order to avoid that support is diverted towards other purposes.

\section{Police, combating transnational crimes and terrorism}

France commented that given their transnational nature, activities in this area have by definition national and international spill-overs, which is in line with the philosophy of TOSSD. Areas that were proposed for inclusion are:

- Rule of law-based criminal justice system.

- Fight against terrorism.

- Fight against national and transnational organised crime, including illicit trafficking.

- Cybersecurity.

At the same time, France proposed to follow a very cautious approach in terms of accounting these types of activities in TOSSD and proposed very strong safeguards (see chapter 13 on safeguards).

\section{Military activities}

France emphasised that activities implemented by military actors should not be excluded a priori. In terms of coverage in this area, France proposed the following:

- Include structural and long-term co-operation and exclude operational and tactical support. Specific structural activities that were proposed for inclusion are:

- Strengthening governance within defence institutions (ex: reform of human resources system, anti-corruption measures).

- Reinforcing the security forces' professionalism and thematic expertise in a specific field (ex: military medicine, cybersecurity), with the exception of kinetic capabilities.

- All kinetic activities, combat operations but also activities aiming at strengthening combating capacities should be excluded. This would exclude all military operations that have "the mandate of defending a specific interest by the use of force" such as the French-led operation Barkhane in the Sahel. 


\section{Safeguards proposed by France for recording peace and security expenditures in TOSSD}

France stressed the inherent risks associated with the implementation of peace and security activities and agreed that caution must be taken when defining the boundary between peace and security expenditures that contribute to sustainable development and the ones which do not. It was recognised that in some cases unintended negative consequences can occur, for example through the misuse of the support provided. However, for France these cases are exceptions and the well-known risk of aid misuse shall "not outweigh the necessity to provide support to fragile countries when needed". In order to mitigate these risks, France stressed that programming in this field should emphasise the link between accountability and effectiveness of security sector actors and, to this end, proposed a number of safeguards.

\section{Holistic and integrated approach and partnerships among various state actors (the French "3 Dimensions" approach)}

During the pilot study, France highlighted the critical importance of holistic and integrated approaches between development, diplomacy (political) and security actors in order to effectively end conflicts and ensure that the crisis exiting is sustainable. The so-called "3 Dimensions" (3D) approach is based on the integration and co-ordination between:

- Conflict prevention and post-conflict development through traditional development activities (provided by the MEFA as well as by its two implementing agencies the French Development Agency and Expertise France).

- Short-term and quick-impact humanitarian and stabilisation activities in response to crises (provided by the Crisis and Support Centre, MEFA).

- Longer-term structural security co-operation (provided by the Security and Defence Co-operation Directorate, MEFA, and Expertise France) as well as support to the democratic governance of the security sector actors (provided by the Directorate for Sustainable Development, MEFA) ${ }^{57}$.

- In areas where the French army is deployed, the co-ordination extends also to the French Ministry of Armed Forces ${ }^{58}$.

\section{Human rights due diligence, rule of law-based approaches, and anti-corruption measures}

In order to mitigate the risk of adverse impact on the SDGs, France proposed several safeguards for peace and security activities, in particular:

\footnotetext{
${ }^{57}$ For example, there is a protocol of partnership between the French Agency of Development and the Security and Defence Co-operation Directorate.

58 Since 2016, there is a memorandum of understanding between the French Development Agency and the Ministry of Armed Forces.
} 
- Overarching frameworks explicitly respecting human rights, democratic governance and rule of law principles,

- Concrete oversight and accountability mechanisms, and

- Transparency in definition and implementation. This includes the political announcement of the co-operation agreement together with the nature the activities involved, a communication on tangible results brought about by the co-operation, a parliamentary review, through written questions, of the nature, cost and implementation of the activities and, finally, the external auditing of the activities.

France recommended to establish methodological safeguards, such as the conduct of strong risk assessments considering potential aid diversion and to put in place measures to prevent and address it. The project methodology should systematically be anchored in a framework of democratic governance and human rights and it should demonstrate its ability to strengthen it.

In general, support aiming at providing or training on the use of lethal equipment should not be eligible to TOSSD.

Interviews conducted during the pilot confirmed that France puts in place the recommended safeguards in the field of human rights due diligence, rule of law-based approaches, and anti-corruption measures:

- The support provided by the French Development Agency in the field of peace and security, especially through its activities related to crisis prevention and response, does entirely fall under Official Development Assistance and is already subject to the strict eligibility rules and safeguards associated with ODA. The mandate of the French Development Agency as currently defined does not cover security sector reform and governance activities.

- The French MEFA, in particular its entities that provide security support, do include these safeguards in their co-operation. Examples of mechanisms and principles that are put in place include:

- A "Do no harm" and a human rights based approach implemented both at the strategic and operational level.

○ Strengthened monitoring and evaluation procedures upstream, during and downstream of projects.

○ Monitoring and accountability frameworks based on international standards and practices.

- Tools to evaluate the actors and financing networks.

- Strict screening processes that allow to select reliable and reputable actors who have no human rights abuses background and are able to mitigate security and financial risks.

- Project monitoring through regular progress reports and field audits conducted by third parties.

- Implementation of the Financial Action Task Force (FATF) recommendations in order to combat money laundering and financing of terrorism.

- As regards the French Ministry of Armed Forces, the interviews highlighted that the design of its co-operation programmes and budget do not allow extracting a 
specific part contributing to human rights and rule of law. However respect of human rights and rule of law are taken into account in each programme.

- In order to systematise human rights due diligence by ministries, France published in June 2018 its new inter-ministerial strategy on crisis prevention and response entitled "Prevention, Resilience and Sustainable Peace (2018-2022)"59, which includes efforts by all relevant Ministries to ensure that co-operation programmes follow a human rights-based approach.

\section{Ownership of the recipient country (national/ local authorities)}

France emphasises also the necessity of local ownership, which is key to ensure sustainability. Other providers, such as UNODC and the United Kingdom, but also recipient countries (e.g. Nigeria, the G7+ group of fragile states) have also stressed the necessary condition of ownership and alignment with national strategies as defined by the recipient country.

\section{Safeguards closely monitored by the TOSSD governance body}

In terms of monitoring compliance with these safeguards and principles, France expressed the view that the criteria should "be closely monitored through an effective process, led by the TOSSD governance structure based on appropriate resources".

59 https://www.diplomatie.gouv.fr/IMG/pdf/meae_strategie_fragilites_en_bat_web_cle4979681.pdf 


\section{Presentation of the co-operation actors and TOSSD estimates on peace and security expenditures by France}

Funding for the French co-operation in the field of peace and security comes from three main sources in the budget law:

- The programme 209, "solidarity with developing countries", channelled through the MEFA (Directorate for Sustainable Development, Crisis and Support Centre, Directorate for United Nations and International Organisations, Security and Defence Co-operation Directorate). An important part of the budget of this programme is also channelled through the French Development Agency.

- The programme 105, "action of France in the world", channelled through the Security and Defence Co-operation Directorate of the MEFA.

- Various programmes under the responsibility of the Ministry of Armed Forces.

Programme 209, "solidarity with developing countries", the French Development Aid

The programme 209, "solidarity with developing countries", is one of the two programmes in the French budget law used to finance Official Development Assistance ${ }^{60}$. It was allocated a total amount of EUR 3.2 billion for 2019. The first objective set by the programme is to directly contribute to the SDGs ${ }^{61}$. It includes several channels for peace and security co-operation:

- The emergency and crisis aid managed by the Crisis and Support Centre, the MEFA's entity that has the responsibility to respond to crisis situations. Its Centre for Humanitarian and Stabilisation Operations (COHS) is composed of two branches, the Humanitarian Unit and the Stabilisation Unit, with the latter supporting a number of rehabilitation activities, including the restoration of national security (see below the section on the Stabilisation Unit). The COHS's funding tool is the emergency humanitarian fund. In 2019, it was allocated EUR 45 million in the budget law, including EUR 5 million dedicated to demining. In addition, the COHS managed a EUR 50 million special programme for Syria as well as a special EUR 5 million fund for victims of religious and ethnic violence.

- In addition, the Directorate-General for Globalization, Culture, Education and International Development (DGM) manages the post conflict and crises exiting budgetary aid (EUR 14.1 million in 2019), and food aid (EUR 39 million).

60 The other programme supporting Official Development Assistance is the programme 110, "economic and financial development assistance". It is under the responsibility of the Ministry for the Economy and Finance.

${ }^{61}$ See the draft budget law for 2019, "Extrait du Bleu Budgétaire de la Mission: Aide Publique au Développement" https://www.performancepublique.budget.gouv.fr/sites/performance_publique/files/farandole/ressources/2019/pap/pdf/DBG PGMPGM209.pdf 
- The Security and Defence Co-operation Directorate of the MEFA receives also an annual budget from this budgetary programme (EUR 2.3 million in 2019) to implement national and regional projects on capacity building for security forces and the fight against drug trafficking, and capacity building for civil protection. These projects are mainly implemented in sub-Saharan Africa as well as North Africa and Middle East.

- The Peace and Resilience Fund (MINKA), created upon decision of the Interministerial Committee for International Cooperation and Development and implemented by the French Agency for Development is aimed at preventing and mitigating crises and their impact, focusing on four regions: the Sahel region, Middle East, Central African Republic and countries around Lake Chad. The 2018 budget of MINKA reached EUR 109 million, 209 million are budgeted for 2019 and the same amount is expected for 2020. MINKA supports long-term (multi-year financial commitments) activities in areas such as access to basic services, food security, education and youth integration, infrastructure rehabilitation or support to victims of conflict and violence. These activities are already tracked in international development statistics.

- The Directorate for United Nations and International Organisations of the MEFA also provides voluntary contributions to $\mathrm{UN}$ agencies implementing humanitarian aid.

\section{The Stabilisation unit}

The French MEFA has recently formulated a French approach to stabilisation (Approche française de la stabilisation, 2019). The Stabilisation unit supports quick and rapidly disbursed emergency rehabilitation projects ${ }^{62}$ with the objective to support post-crisis recovery and lay the groundwork for more sustainable recovery. One of the main criteria of intervention is the inability of the State to support, alone, the process of exiting the crisis. Stabilisation is seen as a transitory phase between humanitarian and development action (continuum humanitarian-stabilisation-development). In order to support the sustainable way out of the crisis, stabilisation aims to:

- Strengthen the capacity of a State, characterised by a political crisis, to perform its basic functions and restore its legitimacy in the eyes of local populations. This includes governance and the restoration of security, based on four main lines of action: demining, strengthening the capacities of the security forces, the support to their development and enhancement of their accountability toward local populations.

- Support vulnerable populations through quick-impact actions, in particular by facilitating the access to basic services, supporting social and economic rehabilitation and strengthening of dialogue and civil society.

The Stabilisation unit sees its activities as fully aligned with SDG 16. In 2019, the Stabilisation unit's total budget was EUR 47 million (including the special programme for Syria). The budget allocated to supporting security was EUR 5.5 million, including all demining activities and support to security actors (civilian protection, interior security

${ }^{62}$ The duration of the projects can be up to 18 months and their size can range from EUR 30000 to EUR 2 million. 
forces or armed forces). All activities of the Stabilisation unit are reportable as ODA (on the 209 budgetary programme), and should be considered as TOSSD eligible.

In order to mitigate the risks inherent to peace and security activities, the Stabilisation unit applies a number of safeguards and principles:

- "Do no harm" approach implemented both at the strategic and operational level.

- Monitoring and accountability frameworks based on international standards and practices.

- Tools to evaluate the actors and financing networks.

- Strict screening processes that allow to select reliable and reputable actors which have no human rights abuses background and are able to mitigate security and financial risks.

- Project monitoring through regular progress reports and field audits and evaluations conducted by third parties.

- Implementation of the Financial Action Task Force (FATF) recommendations in order to combat money laundering and financing of terrorism.

\section{Programme 105, "action of France in the world", the French structural security and co-operation}

The programme 105 includes three main objectives:

- Strengthening of the international security and the security of the French. This objective includes the training and co-operation actions of the Security and Defence Co-operation Directorate of the MEFA (DCSD - EUR 102 million).

- Promoting multilateralism and building Europe. This objective includes the financing of 83 international organisations (USD 726.7 million), $45 \%$ of which is allocated to peacekeeping operations.

- Ensuring an efficient diplomatic service.

\section{The structural peace and security co-operation: the Security and Defence Cooperation Directorate (DCSD - EUR 102 million)}

The adoption of Agenda 2030 prompted adjustments to the institutional setting and procedures for dealing with co-operation in the field of security and defence. In France, the DCSD (Direction de la co-opération de sécurité et de défense) of the MEFA, with its staff from various Ministries (Defence, Interior, Foreign Affairs, Customs, Justice) posted in Paris and abroad (network of 320 international technical experts embedded in the partners' administration and security forces) integrated the objectives of sustainable security and especially the realisation of SDG16 into the implementation of its projects.

DCSD is responsible for providing the structural and long-term French security and defence co-operation. The co-operation is provided by military or law-enforcement experts in areas such as joint-army capacities, support to peacekeeping missions, domestic security and protection of civilians (including against terrorism), health, cybersecurity, illegal trafficking and borders control, maritime security and aviation security. Part of the activities of the DCSD are already tracked today in international development finance statistics. The DCSD viewed its activities as eligible under TOSSD, as they are all 
explicitly linked to SDG 16. The security and defence co-operation is provided through the 17 Regional Oriented National Schools (RONS), which generally include one-third of the students from the host country, the two remaining thirds originating from other countries in the region. Examples of schools and activities include:

- The school of paramedical personnel in Niamey, which France determines contributing to SDG target 16.1 (EUR 632834 in 2017).

- The international school for the enhancement of the judicial police practices in Djibouti, SDG target 16.3 (EUR 24000 in 2018). The school has two objectives: (i) the fight against national and international crime and the strengthening of the rule of law, and (ii) the creation of a centre of excellence in judicial and scientific police.

- The training centre for demining and depollution in Benin, SDG target 16.1 (EUR 508000 in 2017).

- The Higher Education Institute for Civil Protection in Burkina Faso, SDG 16 (EUR 507000 in 2017)

- The interregional institute for maritime security in Côte d'Ivoire, SDG 16 (EUR 929000 in 2017). The objective of the school is to promote a secure, clean and sustainable maritime zone in the Gulf of Guinea.

- The international school for security forces in Cameroon, SDG 16 (EUR 497000 in 2017).

Approximately $85 \%$ of total expenditures incurred by the DCSD are currently not reported as ODA and not captured in international statistics on development finance. These expenditures (EUR 85 million) were reported in the TOSSD Data Survey as contributing to SDG 16 and cover activities related to counter-terrorism, the fight against organised crime and the support to the military. Training and capacity-building activities in the area of counter-terrorism are provided through the regional school in Abidjan. The school, which is managed in co-operation with the Ministry of Armed Forces and the Ministry of Justice, includes a study centre and a training centre for counter-terrorism forces. Based on the proposed eligibility criteria, also supported by France, activities aiming at strengthening combating capacities would not be covered in TOSSD.

The DCSD explained that they did take risk into consideration in the implementation of their activities and described the several safeguards that they apply to conduct their activities in risky areas:

- Strict selection of individuals in partner countries that will benefit from the training.

- Commitment by the individuals to respect the deontological code.

- Article 40 of the Code of criminal procedure which stipulates that corruption needs to be signalled; Budapest Convention on cybercrime.

- Good governance promotion / human rights due diligence /anti-corruption measures, in a transparent framework.

In terms of mobilisation of additional resources, the DCSD benefits also from external public financing (e.g. from the EU or Denmark), which in TOSSD is reported by the original provider. The DCSD also implements projects that mobilisation private finance (expertise) which France could report in TOSSD as private finance mobilised through 
official interventions. For example, the DCSD is currently developing a project where engineers will be freely mobilised from private companies to provide training in cybersecurity.

\section{Programme 178, "the preparation and use of armed forces" the Ministry of Armed Forces}

In contrast to DCSD, the Ministry of Armed Forces does not have a mandate to contribute to SDGs, and its expenditures would generally not fall under TOSSD. In addition, the interviews with representatives of the Ministry of Armed Forces revealed that any extraction of activities potentially reportable on TOSSD from their budget would be difficult in practice because of the way their budget is designed. However, there are marginal expenditures that could count, also in the context of Barkhane - the French military operation in the Sahel - such as civil-military actions that have the objective of improving acceptance of the force by local populations. These activities are already captured in Official Development Assistance.

\section{Others}

The programme 218 finances Tracfin, a service of the Ministry of the Economy and Finance which fights illegal financial operations, money laundering and financing of terrorism. Tracfin's missions are to collect and analyse financial intelligence and do investigation, including in collaboration with foreign financial intelligence units. Its activities include seminars and technical assistance to developing countries. The global budget is increasing and was EUR 6.7 million in 2019 (excluding remunerations), but only a part of it would probably be eligible.

The programme 166 from the Ministry of the Interior finances a contribution to Interpol (EUR 3.2 million in 2019).

Various public entities have international co-operation activities through seminars or trainings. On the fight against corruption and illicit flows, punctual technical assistance is provided by customs authorities (DGDDI, Direction générale des douanes et des droits indirects) or law schools (ENM, Ecole nationale de la magistrature).

\section{Conclusion and TOSSD estimate}

In general, the criteria proposed by France correspond well to the recommendations that emerged from the pilot and which were later adopted, with adjustments, by the TOSSD Task Force. As regards the third principle proposed by France on the need to take into account the situation of the recipient country (see chapter 12 above), as mentioned in chapter 9 on law enforcement, the suggestion of discriminating between recipient countries on the basis of their fragility and/or their good performance in terms of governance and human rights was put forward by several interviewees throughout the pilot. However, it seems difficult for TOSSD, which aims to be an inclusive and internationally accepted measure, to introduce a concept of differentiation between recipient countries. In addition, this would contradict the universality of the SDGs. 
Table 14.1. Summary of expenditures by France in support of the SDGs in the field of peace and security, TOSSD estimate for 2018*

\begin{tabular}{lr}
\hline & EUR million \\
\cline { 2 - 2 } Programme 209, "solidarity with developing countries" & 209 \\
Peace and Resilience Fund - MINKA & 100 \\
Crisis and Support Centre & 40 \\
$\quad--$ of which Stabilisation Unit & 102 \\
Programme 105, "action of France in the world" & 2 \\
Security and Defence Co-operation Directorate & 1 \\
Others & 1 \\
Tracfin & \\
Other trainings for the fight against illicit financial flows & 327 \\
Multilateralism & 35 \\
Peace operations & 26 \\
\hline UN peacekeeping* & 22 \\
AMISOM & 3 \\
Organisation for Security and Co-operation in Europe & 4 \\
Disarmament & \\
\hline International Atomic Energy Agency & 1 \\
\hline Comprehensive Nuclear-Test-Ban Treaty Organisation & 3 \\
\hline Organisation for the prohibition of chemical weapons & 13 \\
\hline Law enforcement & 849 \\
\hline United Nations Office on Drugs and Crime & \\
Interpol & \\
International tribunals & \\
\hline International Tribunal Court & \\
TOSSD, estimate & \\
\hline Or & \\
\hline
\end{tabular}

* Or latest data available

Source: Interviews and budgetary documents. 
Part V. Light assessment of the capacity of the organisations / countries met during the pilot to provide TOSSD data on peace and security.

Part V provides a light assessment of the capacity of the organisations / countries met during the pilot to provide TOSSD data on peace and security, and includes a focus on Australia's work to adjust its reporting processes accordingly.

In addition to serving as the basis for developing recommendations to the TOSSD Task Force on the boundaries of TOSSD, the pilot highlighted interest by several bilateral providers and multilateral organisations for reporting their activities in TOSSD. Many bilateral providers that already report their ODA activities to the OECD were able to identify and include, in their response to the TOSSD Data Survey, additional activities in the field of peace and security that support sustainable development, see chapter 15 . Several multilateral organisations that never reported so far to any international statistical system on development finance expressed interest in reporting their activities to TOSSD, as this would increase visibility of their work and contribution to SDGs. The pilot gave the Secretariat the opportunity to initiate a dialogue with multilateral organisations on this topic, see chapter 16 . 


\section{Capacities of countries met during the pilot to provide TOSSD data on peace and security}

In the context of the TOSSD Data Survey, ten bilateral providers and the EU provided data on peace and security beyond ODA. This was the case of France but also Australia, Canada, the Czech Republic, Portugal, Spain, Sweden, Switzerland, Turkey and the United States. The types of activities reported do not necessarily fit in the existing sector classification, which may need to be adjusted in future.

Examples of activities reported in the TOSSD Data Survey include:

- Peacekeeping: UN peacekeeping operations (counted 100\% in TOSSD while only count for $15 \%$ in ODA).

- Disarmament: Strengthen biological safety and security across Asia; strengthen national and regional capacities to detect and interdict illicit cargos of nuclear or other radiological materials; International treaties and conventions: Arms Trade Treaty, Convention on Certain Conventional Weapons, Biological and Toxin Weapons Convention, etc.; Nuclear non-proliferation.

- Fight against terrorism and organised crime: Countering money laundering and the financing of terrorism (e.g. financial intelligence units); International cooperation against Foreign Terrorist Fighters; Support for the implementation of the 19 international legal instruments to fight terrorism; Strengthening international cooperation and information exchange between law enforcement agencies.

Australia, anticipating the scope for some of its non-ODA eligible bilateral engagement with developing countries to fall under the future TOSSD framework has been proactive in adjusting its internal reporting processes. It has developed a specific classification to capture TOSSD peace and security activities (See Box 15.1) and also reflected on possible adjustments to the existing sector and modality classifications (see Annex F). These possible adjustments could be considered by the TOSSD Task Force in future.

The Australian Department for Foreign Affairs and Trade published data on peace and security according to its internal classification, see Table 27 in https://dfat.gov.au/aboutus/publications/Documents/statistical-summary-2015-16.pdf and plans to continue publishing TOSSD data.

The classification excludes "acts of war" (an action by one country against another with an intention to provoke a war or an action that occurs during a declared war or armed conflict between military forces) but includes "post-conflict restoration" support.

\section{Box 15.1. Australian Official Support to Developing Countries: Peace and Security Classification}

1. Peace and security strategic policy engagement
a. Bipartisan engagement
b. Rule of Law implementation and adherence
c. Forums, conferences and facilitated networking
d. Multilateral and regional peace and security organisations
e. Other peace and security engagement not further defined 
2. Peace assistance and support
a. Peacekeeping missions (non-ODA component)
b. Other (non-ODA) humanitarian support provided by defence and security forces
c. Military and police academy education exchanges
d. Uniformed in-field exchanges and operational support
e. Other civil service and field exchanges
$f$. Other peace assistance not further defined

3. Security assistance and support

a. Governance

i. Accountable authorities, including war crime tribunals and courts

ii. Anti-bribery

iii. Civil disobedience control

b. Transnational crime (investigation and response)

i. Transnational migration (human trafficking and people smuggling)

ii. Goods control (contraband smuggling)

iii. Anti-poaching, wildlife and marine life protection

iv. Intelligence gathering and sharing

v. Criminal justice and enforcement

vi. Counter terrorism

c. Infrastructure and assets security

i. Infrastructure protection

ii. Monetary fraud management and tracking

iii. Intellectual property and trade secrets

d. Information security

i. Cyber security

ii. Identity fraud

iii. Information protection and security checks

e. Other security assistance and support

i. Operational policing

ii. Other (non-ODA) expenses incurred in delivery assistance

iii. Other security assistance not further defined

See Annex F for more details on the types of activities included under each category, and examples. Note that Australia will adjust its classification to take into account the agreed TOSSD eligibility criteria. 


\section{Capacity of multilateral institutions met during the pilot to provide TOSSD data on peace and security}

The pilot gave the authors the opportunity to initiate a dialogue on TOSSD reporting with the multiple organisations met.

\section{UN regular budget}

The UN Secretariat's programmes and sub-programmes support Member States in the implementation of the SDGs and can be counted in TOSSD. The documents on the proposed budget provide the necessary level of details (sub-programme description, SDG focus, budget amount) and the TOSSD Task Force Secretariat could use it to populate the TOSSD Survey database. It is the first time that international statistics on development will reflect norm-setting work by the UN Secretariat (mostly excluded from ODA) and its contribution to peace and security and some other international public goods.

In total, 200 sub-programmes were included in the Survey, for an overall amount of USD 2.8 billion, of which a significant share relates to peace and security (see chapter 7). Descriptive information attached to the budget data is very informative (see examples below) and it remains to be discussed with the UN Secretariat whether expenditure data with similar level of details can be reported to TOSSD in future.

Examples of sub-programmes included in the TOSSD data Survey in the field of peace and security are presented below.

\section{Example 1: Section 3 of the UN regular budget, Office of Counter-Terrorism}

- Description: "The objective, to which the Office of Counter-terrorism contributes, is to prevent and counter terrorism and to prevent violent extremism, as and when conducive to terrorism, in all its forms and manifestations in compliance with international law."

- Link to SDG 16: "The objective is aligned with Sustainable Development Goal 16, which is to promote peaceful and inclusive societies for sustainable development, provide access to justice for all and build effective, accountable and inclusive institutions at all levels. Progress towards the attainment of the objective will help to strengthen relevant national institutions, including through international cooperation, for building capacity at all levels, to prevent violence and combat terrorism."

- $\quad$ Amount = USD 1.6 million

\section{Example 2: Section 4 of the UN regular budget, Disarmament, sub-programme 4 on information and outreach}

- Description: "The objective, to which this sub-programme contributes, is to enhance the awareness, understanding and knowledge of Member States and the public for advancing disarmament, non-proliferation and arms control. "

- Links with SDGs 4, 5 and 16: "The objective is aligned with Sustainable Development Goal 4, which is to ensure inclusive and equitable quality education 
and promote lifelong learning opportunities for all. Progress towards the attainment of the objective will help to ensure that all learners acquire the knowledge and skills needed to promote sustainable development, including, among others, through education for the promotion of a culture of peace and non-violence.

The objective is also aligned with Sustainable Development Goal 5, which is to achieve gender equality and empower all women and girls. Progress towards the attainment of the objective will help to ensure women's full and effective participation and equal opportunities for leadership at all levels of decision-making in political, economic and public life.

Finally, the objective is also aligned with Sustainable Development Goal 16, which is to promote peaceful and inclusive societies for sustainable development, provide access to justice for all and build effective, accountable and inclusive institutions at all levels. Progress towards the attainment of the objective will help to strengthen relevant institutions, including through international co-operation to build capacity to prevent violence."

- $\quad$ Amount $=$ USD 1.8 million

\section{UN peacekeeping}

Budget documents for UN Peacekeeping operations are publicly available but provide only for a high-level breakdown of expenditures (see box 7.2). Initial consultations with the UN Secretariat indicate that the UN should be able to provide expenditure data for future TOSSD data collection. For the purpose of the TOSSD Survey, data on providers' contributions to the UN peacekeeping budget were used as proxies in TOSSD Pillar II.

\section{Organisation for the Security and Co-operation in Europe (OSCE)}

OSCE is interested in the TOSSD methodology and the possibility to better capture many of its activities which are multi-country or regional in nature. OSCE activities that are deemed ODA-eligible (74\% in total) are already included in the CRS. However, while OSCE's Financial Report and Statements provide a breakdown of the Unified Budget (EUR 137.8 million in 2018), its financial statements which include extra-budgetary contributions (EUR 22.2 million in 2018) are prepared on an International Public Sector Accounting Standards (IPSAS) basis, which differs from the Unified Budget structure. Due to the comprehensive security approach, many activities related to action against terrorism, security sector reform, etc. are supported by multiple budget units and by extra-budgetary contributions.

\section{UNOCT, UNODC, UNODA and INTERPOL}

These institutions met in the course of the pilot have never reported their activities to an international statistical system on development finance. They all expressed interest in TOSSD and possibly reporting under this new framework which would provide more visibility to their activities. In countering terrorism, the four institutions are part of the UN Global Counter-Terrorism Compact and its Working Group on Resource Mobilisation and Monitoring and Evaluation. Through the Working Group, the four institutions have mapped their activities and resources to streamline technical assistance and align it with technical needs identified by the UN Counter-Terrorism Executive Directorate. The Working Group produces the "Counter-Terrorism Compact Entities Matrix of UN Counter-Terrorism 
Projects and Activities", information that has been included in reports of the SecretaryGeneral on implementation of the Global Counter-Terrorism Strategy ${ }^{63}$, and will feed into TOSSD, i.e. basically projects descriptions/amounts budgeted/SDG focus/beneficiary countries.

\section{UN Office of Counter-Terrorism}

UNOCT is currently examining its capacity to report on TOSSD, given that it already reports project information in its annual reports. Discussions have shown that new purpose codes would be needed to capture the full array of its activities, in particular in the counterterrorism field. Using the "2018 Annual report" and the "UNOCT Consolidated multi-year appeal" for 2019-2020, TOSSD-type data could be derived.

Examples of possible reporting:

- Pillar II: Countering the Financing of Terrorism through Effective National and Regional Action

Build capacity on freezing of assets with a stronger focus on Foreign Terrorism Fighters (FTFs) financing, financial intelligence sharing, risk assessments, and public-private partnerships.

- Pillar II: Supporting regional efforts of the G5 Sahel countries to counter terrorism and prevent violent extremism

Support the G5 Sahel countries in the implementation of the UN Global CounterTerrorism Strategy at the regional level through an "All-of-UN" approach, in close collaboration with UNOWAS and the G5 Sahel Permanent Secretariat.

\section{UN Office on Drugs and Crime (UNODC)}

Reporting information at activity level might be challenging at this stage as the budget system is not based on individual activities. However, information on expenditures is available by country and sector. The differentiation between TOSSD Pillar I and Pillar II might also be challenging for some global programmes that include both activities at the global or regional (e.g. good practices and guidelines) and country level. Another important aspect to mention is that some activities implemented by UNODC are financed by the beneficiary itself (e.g. Colombia).

Examples of possible reporting:

- Pillar I: Support to the establishment of two new Mobile Detection teams of the Counter Narcotics Police (CNPA) in Afghanistan

- Pillar I: Specialised sessions on information and intelligence analysis in Iran

- Pillar I: Legal expertise and training to strengthen the fight against transnational organized crime, terrorism and its financing in Burkina Faso

- Pillar II: World Drug Report

${ }^{63}$ See the 2018 report at https://www.un.org/en/ga/search/view_doc.asp?symbol=A/72/840 


\section{United Nations Office for Disarmament Affairs}

In principle, UNODA would be able to provide information on its programmes financed from voluntary contributions. Data could be broken down by disarmament area and recipient country. However, financial information at activity-level is not available. The reporting on expenditures financed from the regular budget would be more challenging as these are more diffuse and not systematically captured.

\section{INTERPOL}

The discussions have advanced well with INTERPOL, which is determined to co-operate with the Secretariat on TOSSD in general and on reporting in particular. INTERPOL works to foster international law enforcement co-operation, and to that end, projects are implemented nationally, regionally and globally. All projects are designed to enhance the capacity of countries to participate in international police co-operation so they can be considered by default as entailing international spill-over effects. INTERPOL's budget system does not include a breakdown of expenditures by recipient country. Using their "Annual report" and "Investment opportunities" publications, the Secretariat derived examples of TOSSD-type data.

Example of possible reporting:

- Pillar II: Building global capacity to counter cybercrime: INTERPOL has a strong track record for training and capacity building in cyber policing skills. A comprehensive cybercrime training curriculum combining e-learning and classroom training equips participants to deal with evolving crimes in the digital arena. In 2018, INTERPOL delivered training courses to 164 participants from 61 member countries, including first responders, cybercrime investigators, cyber intelligence analysts, decision-makers, prosecutors and judges. 


\section{Conclusions and next steps}

On the basis of the recommendations that emerged from this pilot, the TOSSD Task Force adopted principles and eligibility criteria for including peace and security expenditures in TOSSD (see Reporting Instructions, Annex E).

The first TOSSD Data Survey confirmed the feasibility for providers to report on their peace and security expenditures that contribute to sustainable development. This is promising in terms of increased visibility on expenditures in this field, as called for by many stakeholders.

Starting 2020, a standard data collection on TOSSD will take place on an annual basis. Going forward, the TOSSD governance body is expected to undertake regular reviews of peace and security activities reported in TOSSD in order to examine their alignment with the 2030 Agenda and propose revisions to the eligibility criteria if needed.

Findings of this pilot will be shared with various international fora. Thanks to additional support provided by the European Union, other pilot studies, focusing on selected countries' perspective on TOSSD, will be conducted in the course of 2020, including one in Bangladesh planned for first quarter of 2020 to further inform the work of the Task Force and test the various parameters and methodologies of TOSSD. 


\section{Annex A. SDG 16 and related targets}

Goal 16. Promote peaceful and inclusive societies for sustainable development, provide access to justice for all and build effective, accountable and inclusive institutions at all levels

16.1 Significantly reduce all forms of violence and related death rates everywhere.

16.2 End abuse, exploitation, trafficking and all forms of violence against and torture of children.

16.3 Promote the rule of law at the national and international levels and ensure equal access to justice for all.

16.4 By 2030, significantly reduce illicit financial and arms flows, strengthen the recovery and return of stolen assets and combat all forms of organized crime.

16.5 Substantially reduce corruption and bribery in all their forms.

16.6 Develop effective, accountable and transparent institutions at all levels.

16.7 Ensure responsive, inclusive, participatory and representative decision-making at all levels.

16.8 Broaden and strengthen the participation of developing countries in the institutions of global governance.

16.9 By 2030, provide legal identity for all, including birth registration.

16.10 Ensure public access to information and protect fundamental freedoms, in accordance with national legislation and international agreements.

16.a Strengthen relevant national institutions, including through international cooperation, for building capacity at all levels, in particular in developing countries, to prevent violence and combat terrorism and crime.

16.b Promote and enforce non-discriminatory laws and policies for sustainable development. 


\section{Annex B. List of topics for consultation with experts, at a meeting, through a written questionnaire to the International Network on Conflict and Fragility (INCAF), and during missions}

\section{a. Scope of TOSSD in the field of peace and security}

What are the areas of support where providers actively contribute to peace and security? Can they be linked to SDG 16 targets? Is there a recommended typology of activities for framing the discussion? See below proposed starting point, inspired from classification used in Australia for TOSSD activities in the field of peace and security.

Peace and security expenditures

- Development enablers

- Peacekeeping missions

- Peacebuilding, conflict prevention and resolution

- Disarmament (small arms and light weapons, mine clearance, mass-destruction weapons, nuclear)

- Humanitarian assistance provided by defence and security forces

- International tribunals for crimes of war

- Security system reform

- Strategic security planning and policy advice

- Military and police academy education exchanges

- Other civil service policy and field training exchanges

- Transnational migration and goods control

- Preventing and combating terrorism and transnational crime

- Infrastructure security

- Cyber security

- Monetary security

- Anti-poaching, wildlife and marine resource protection

- Global and regional contributions

○ Research

- Advocacy

- Forums, conferences and facilitated network development

- Norm and standard-setting activities (e.g. Arms trade treaty)

What are the modalities used to deliver peace and security contributions? E.g. project, technical assistance (including through secondments), budget support, norms and standard setting, advocacy work, conferences. 
Are the contributions cross-border resource flows to TOSSD-eligible developing countries (pillar I) or contributions at a global level (pillar II)?

In the case of contributions at global level, benefitting both developing and developed countries, what criteria can help decide on their inclusion/exclusion?

What could be the best approach for developing eligibility criteria? Alternative approaches were discussed by the Task Force: i) migrating ODA rules into TOSSD as a starting point; ii) building TOSSD rules with little attention to how the question is treated in $\mathrm{ODA}^{64}$; or iii) developing a positive list of eligible activities to clearly define the boundaries on this complex topic. Experts are specifically asked to indicate the activities that they think should be eligible under TOSSD, and the activities (if any) that they think should not be eligible under TOSSD. ${ }^{65}$

Are safeguards needed? Why? Which safeguards? (See the existing safeguards in ODA rules in Annex IV.) In particular, if the use of force is admitted under TOSSD, should it be associated to specific safeguards? Same goes for direct support to the partner country's military.

To avoid ambiguity and interpretation issues, the eligibility rules of peace and security expenditures under TOSSD should be straightforward. The direct link to an SDG target is a key element, but there may be a need to set some additional clear boundaries, to avoid recording under TOSSD e.g. unilateral military interventions of provider countries or contributions to developing countries' defence budgets. Examples of possible safeguards could be:

- a blanket exclusion of financing weapons.

- compliance with Oslo Guidelines (using military only as a last resort, humanitarian principles of humanity, neutrality and impartiality).

- the requirement that peacekeeping operations be mandated by the UN to be recorded under TOSSD.

\section{b. Is the statistical methodology proposed for TOSSD, in particular pillar II, sound and feasible?}

Experts are invited to comment the draft generic definition of pillar II and related eligibility criteria and to test the application of the proposed decision tree to multiple types of activities in the field of peace and security.

\section{c. What are the existing sources of data on expenditures in the field of peace and security?}

\footnotetext{
${ }^{64}$ In the ODA context, the peace/development nexus has long been discussed and current rules reflect a tradeoff - on one hand, it is necessary to respond to developmental challenges in conflict situations, including in relation to military actors, and on the other hand there is a need to maintain the two fields clearly separate to avoid militarisation of aid. With the Agenda 2030 and TOSSD, the discussion should be simpler as peace and security clearly has a space on its own.

${ }^{65}$ Are there examples of non-sustainable contributions in the context of peace and security activities?
} 


\title{
Annex C. List of consultations carried out in the context of the TOSSD pilot on peace and security
}

\author{
Expert workshop held on 5 February 2019
}

Participants: TOSSD Co-Chair Laurent Sarazin, International Dialogue on Peacebuilding and Statebuilding (one representative from INCAF, G7+ and CSPPS), international organisations (Geneva Centre for the Democratic Control of Armed Forces - DCAF, Interpol, North Atlantic Treaty Organisation - NATO, Organisation for Economic Co-operation and Development - OECD, UN Department of Operational Support - DOS, Liaison Office for UN Peace and Security, UN Office on Drugs and Crime - UNODC), research institutes (Institute for Security Studies - ISS, Stockholm International Peace Research Institute - SIPRI), Civil Society Organisations (European Peacebuilding Liaison Office - EPLO, Global Initiative Against Transnational Organized Crime, OXFAM, Saferworld), provider countries (Australia, France, EU).

Written contributions received from workshop's participants: CSOs submission (Civil Society Organisations, $2019_{[10]}$, , France and SIPRI.

\section{Questionnaire sent to INCAF}

Responses received from: Czech Republic, Greece, Portugal, United Kingdom, UN Peacebuilding Office.

\section{Bilateral consultations:}

- Multilateral organisations: International Atomic Energy Agency (IAEA), International Criminal Police Organisation (INTERPOL), Organisation for Security and Co-operation in Europe (OSCE), UN Secretariat (Office of the Controller), UN Department of Operational Support (DOS), UN Office for Disarmament Affairs (UNODA), UN Office on Drugs and Crime (UNODC), UN Office of Counter-Terrorism (UNOCT), World Bank.

- Partner countries: Burkina Faso (interview with former Prime Minister, interview with the Ministry of Foreign Affairs); Indonesia (interview with the Ministry of Foreign Affairs, International security and disarmament); Nigeria (written Questionnaire); G7+ represented at the workshop.

- Provider country: in-depth consultation with France. Consultations conducted with: the French Ministry for Europe and Foreign Affairs - MEFA (the DirectorateGeneral for Globalization, Culture, Education and International Development; the Security and Defence Co-operation Directorate; the Crisis and Support Centre); the Ministry for the Economy and Finance; the French Agency for Development; the Ministry of Armed Forces.

- Academics, research institutes and CSOs: Global Initiative Against Transnational Organized Crime; Hertie School of Governance; International Centre for the Study of the Profession of Arms; International Peace Institute; Pathfinders for Peaceful, Just and Inclusive Societies (SDG 16+). 


\section{Annex D. UN regular budget - summary}

Table A D.1. UN regular budget, proposal for 2020 - summary in USD

\begin{tabular}{|c|c|c|c|}
\hline & $\begin{array}{c}2018 \\
\text { expenditure }\end{array}$ & $\begin{array}{c}2019 \\
\text { appropriation }\end{array}$ & $\begin{array}{l}2020 \text { estimate (after } \\
\text { recosting) }\end{array}$ \\
\hline Part I. Overall policymaking, direction and coordination & 368674.9 & 399776.8 & 406404.5 \\
\hline Section 1. Overall policymaking, direction and coordination & 61573.1 & 75995.8 & 78640.2 \\
\hline $\begin{array}{l}\text { Section 2. General Assembly and Economic and Social } \\
\text { Council affairs and conference management }\end{array}$ & 307101.7 & 323781.0 & 327764.3 \\
\hline Part II. Political affairs & 724382.6 & 784136.7 & 775855.5 \\
\hline Section 3. Political affairs & 658573.5 & 715666.3 & 705660.0 \\
\hline Section 4. Disarmament & 12379.4 & 12959.3 & 13692.8 \\
\hline Section 5. Peacekeeping operations & 49577.0 & 51596.8 & 52348.0 \\
\hline Section 6. Peaceful uses of outer space & 3852.8 & 3914.3 & 4154.7 \\
\hline Part III. International justice and law & 61677.8 & 62039.7 & 87195.8 \\
\hline Section 7. International Court of Justice & 25342.1 & 24681.7 & 27040.1 \\
\hline Section 8. Legal affairs & 36335.7 & 37358.0 & 60155.7 \\
\hline Part IV. International cooperation for development & 243399.6 & 243637.7 & 253407.8 \\
\hline Section 9. Economic and social affairs & 80292.0 & 82013.0 & 84181.0 \\
\hline $\begin{array}{l}\text { Section 10. Least developed countries, landlocked developing } \\
\text { countries and small island developing States }\end{array}$ & 5526.8 & 5508.1 & 5756.7 \\
\hline $\begin{array}{l}\text { Section 11. United Nations support for the New Partnership for } \\
\text { Africa's Development }\end{array}$ & 7765.4 & 8286.4 & 8663.4 \\
\hline Section 12. Trade and development & 68669.2 & 68273.4 & 70543.3 \\
\hline Section 13. International Trade Centre & 18679.8 & 19110.9 & 19397.6 \\
\hline Section 14. Environment & 20486.9 & 20482.3 & 21417.7 \\
\hline Section 15. Human settlements & 11544.3 & 11162.6 & 11794.8 \\
\hline $\begin{array}{l}\text { Section 16. International drug control, crime and terrorism } \\
\text { prevention and criminal justice }\end{array}$ & 21473.8 & 20435.7 & 22428.6 \\
\hline Section 17. UN-Women & 8961.3 & 8365.3 & 9224.7 \\
\hline Part V. Regional cooperation for development & 278120.3 & 297877.5 & 309672.6 \\
\hline Section 18. Economic and social development in Africa & 70263.6 & 84176.7 & 87704.8 \\
\hline $\begin{array}{l}\text { Section 19. Economic and social development in Asia and the } \\
\text { Pacific }\end{array}$ & 52117.5 & 53274.4 & 53395.8 \\
\hline Section 20. Economic development in Europe & 34180.6 & 31973.3 & 33150.6 \\
\hline $\begin{array}{l}\text { Section 21. Economic and social development in Latin America } \\
\text { and the Caribbean }\end{array}$ & 57450.5 & 58449.5 & 59933.9 \\
\hline Section 22. Economic and social development in Western Asia & 35533.3 & 37115.8 & 38321.0 \\
\hline Section 23. Regular programme of technical cooperation & 28574.8 & 32887.8 & 37166.5 \\
\hline Part VI. Human rights and humanitarian affairs & 203453.2 & 200331.1 & 189167.6 \\
\hline Section 24. Human rights & 114353.0 & 111633.7 & 98714.3 \\
\hline $\begin{array}{l}\text { Section 25. International protection, durable solutions and } \\
\text { assistance to refugees }\end{array}$ & 42954.4 & 43275.1 & 42833.2 \\
\hline Section 26. Palestine refugees & 28457.6 & 27525.4 & 29201.8 \\
\hline Section 27. Humanitarian assistance & 17688.3 & 17896.9 & 18418.3 \\
\hline Part VII. Global communications & 91400.6 & 91893.1 & 94774.4 \\
\hline Section 28. Global communications & 91400.6 & 91893.1 & 94774.4 \\
\hline Part VIII. Common support services & 103084.4 & 304603.9 & 304105.3 \\
\hline \multicolumn{4}{|l|}{ Section 29. Management and support services } \\
\hline $\begin{array}{l}\text { A. Department of Management Strategy, Policy and } \\
\text { Compliance }\end{array}$ & - & 55153.6 & 57054.5 \\
\hline B. Department of Operational Support & - & 97162.8 & 88614.7 \\
\hline
\end{tabular}




\begin{tabular}{|c|c|c|c|}
\hline C. Office of Information and Communications Technology & - & 47834.4 & 49887.4 \\
\hline E. Administration, Geneva & 69230.9 & 69300.0 & 71481.2 \\
\hline F. Administration, Vienna & 18565.7 & 18757.9 & 19367.2 \\
\hline G. Administration, Nairobi & 15287.7 & 16395.2 & 17700.3 \\
\hline Part IX. Internal oversight & 21428.6 & 20569.1 & 21662.8 \\
\hline Section 30. Internal oversight & 21428.6 & 20569.1 & 21662.8 \\
\hline $\begin{array}{l}\text { Part X. Jointly financed administrative activities and } \\
\text { special expenses }\end{array}$ & 83975.3 & 72247.4 & 82539.6 \\
\hline Section 31. Jointly financed administrative activities & 6194.0 & 6300.7 & 6328.4 \\
\hline Section 32. Special expenses & 77781.3 & 65946.7 & 76211.2 \\
\hline Part XI. Capital expenditures & 36239.4 & 73004.6 & 16591.7 \\
\hline $\begin{array}{l}\text { Section 33. Construction, alteration, improvement and major } \\
\text { maintenance }\end{array}$ & 36239.4 & 73004.6 & 16591.7 \\
\hline Part XII. Safety and security & 125352.1 & 121062.6 & 120788.1 \\
\hline Section 34 . Safety and security & 125352.1 & 121062.6 & 120788.1 \\
\hline Part XIII. Development Account & 14199.4 & 14199.4 & 14199.4 \\
\hline Section 35. Development Account & 14199.4 & 14199.4 & 14199.4 \\
\hline Part XIV. Staff assessment & 258900.1 & 262099.0 & 263543.8 \\
\hline Section 36. Staff assessment & 258900.1 & 262099.0 & 263543.8 \\
\hline Total, regular budget & 2614288.3 & 2947478.6 & 2939908.9 \\
\hline
\end{tabular}

Source: A/74/6 (Introduction) - Proposed programme budget for 2020, Foreword and introduction (Annex II, Schedule, available from ny.un.org/doc/UNDOC/GEN/N19/142/59/pdf/N1914259.pdf?OpenElement.

https://documents-dds- 


\section{Annex E. Further information on OSCE work}

\section{Comprehensive approach to security}

This approach identifies three "dimensions" of security:

a) politico-military dimension: fostering arms control and confidence and security building measures; building border security and management capacities; helping reform military and police forces; destroying small arms and conventional ammunition and ensuring safe stockpile management;

b) economic and environmental dimension: enhancing economic co-operation and good governance; addressing environment and security risks and promoting transboundary environmental co-operation; promoting co-operation on energy security;

c) human dimension: strengthen democratic institutions; hold genuine and transparent democratic elections; promote gender equality; ensure respect for human rights, media freedom, the rights of persons belonging to national minorities and the rule of law; and promote tolerance and non-discrimination.

\section{The Forum of Security Co-operation}

The Forum implements confidence and security-building measures to regulate the exchange of military information and mutual verification between states, as well as the OSCE Code of Conduct on Politico-Military Aspects of Security is a key document in this regard and sets out basic norms for the democratic control of armed and security forces, as well as ensuring human rights and fundamental freedoms for armed forces personnel. The Forum also develops norms and provides practical assistance to address the proliferation of illicit small arms and light weapons and deals with non-proliferation of weapons of mass destruction.

\section{Security Sector Governance and Reform}

As national security sectors have an important role to play in working towards achieving the objectives of Goal 16, the OSCE's efforts in the area of Security Sector Governance and Reform (SSG/R) are directly connected. Supporting the participating States in strengthening the governance of their security sectors represents an integral part of the OSCE's work to prevent conflict, promote comprehensive security and sustain peace. Identifying potential deficiencies in a given country's security sector and their possible impact on the country's capacities to address relevant security challenges is part of the OSCE's early-warning efforts. Through our network of field operations and institutions, the OSCE supports long-term national efforts to strengthen their resilience and adapt their responses to changing security needs and evolving situations. Much progress has been achieved in recent years in strengthening the effectiveness of the OSCE's support to national SSG/R processes. In his first report on the OSCE approach to SSG/R (2019), the Secretary-General outlined the long track record related to SSG/R and called for further efforts exploring the contribution of SSG/R in these contexts. 
Cyber

OSCE also increasingly works on issues related to cyber - including how cyber/ICT security influences interstate relations, cybercrime, the use of the Internet for terrorist purpose, human trafficking (https://www.youtube.com/watch? $v=\mathrm{jCaTL} 9 \mathrm{x} 7 \mathrm{Dg}$ ). The unique characteristics of ICTs have considerably increased the potential for misperceptions, miscalculations and even tensions between states as they grapple with questions of intent, attribution, rules and norms. In response, OSCE participating States are working on confidence-building measures to reduce the risks of conflict between $\mathrm{pS}$ stemming from the use of ICTs. They are designed to make cyberspace more predictable and offer concrete tools and mechanisms to avoid misunderstandings. See more at https://www.osce.org/cyber-ict-security. OSCE also works with law enforcement to build capacity to combat cybercrime and cyber-enabled crime (https://www.osce.org/secretariat/420965 ) 
Annex F. Contribution by Australia on possible adjustments to TOSSD sector and modality classifications in the area of peace and security

\section{Possible revised sectors for peace and security}

15300 Peace and security

15310 Justice, law and order policy, planning and administration

15311 Transnational crime

15312 Infrastructure security

15313 Cyber security

15314 Monetary security

15320 Police

15315 Countering violent extremism

15321 Police governance, policy, planning and administration

15322 Trafficking and illegal goods control

15323 Infrastructure security

15324 Cyber security

15325 Money laundering

15326 Peacekeeping missions

15327 Policy academy and field exchanges

15328 Firearm and weapons management and use

15330 Fire and rescue services

15340 Border control

15341 Immigration policy, planning and administration

15342 Transnational migration and goods control

15343 Anti-poaching, wildlife and marine resource protection

15350 Judicial affairs

15360 Ombudsman

15370 Prison

15371 Prison governance, policy, planning and administration

15372 Countering violent extremism and other prison reform programmes

15380 Defence

15381 Defence governance transparency and civilian oversight

18382 Defence humanitarian and human right (ODA) assistance

15383 Peacekeeping missions

15384 Military (non war) academy and field exchanges, and other friendly special assistance

Possible additional modalities (could apply to all sectors, not only peace and security)

- Strategic policy engagement

- Research collaboration

- Networks, conferences, meetings

- Support for global and regional organisations 


\section{Classification used by Australia, types of activities and examples (see Box 15.1 for an overview of the classification)}

\section{Strategic Policy Engagement}

a. Bipartisan engagement encompasses mutually beneficial engagement between Australia and ODA-eligible countries.

Example: In December 2018 the Australian Federal Police (AFP) renewed the Taskforce Blaze agreement, the Joint Agency Arrangement on Economic Crime Cooperation with Chinese law enforcement agencies and signed a new Memorandum of Understanding (MOU) with the Chinese National Commission of Supervision (NCS) on anti-corruption law enforcement co-operation.

b. Rule of Law implementation and adherence encompasses assistance efforts that enforce the implementation of sanctions or relate to implementing international sanctions. It also includes activities that are ODA in nature but include conditions whereby the recipient developing country must adhere to international rule of law compliance.

Example: Technical workshop in West Africa on implementing the United Nations Security Council (UNSC) Sanction Committee on North Korea. The purpose of the workshop is to ensure West African developing countries are not subject to trade sanctions due to non-compliance. The workshops will improve West African developing countries technical understanding and implementation of UNSC sanctions against the Democratic People's Republic of Korea through capacity building for organisations and government of how to implement these sanctions.

c. Forums, conferences and facilitated networking encompasses support provided to assist in mutually beneficial dialogue and networking. In the case of development agendas, attendance at conferences, forums and networks is not, in itself, considered an integral part in delivering aid. While facilitating networking and sharing of information, it does not guarantee an aid outcome.

Example: The DAC has excluded from ODA, meetings and forums with a global mandate agenda together with the cost of receiving developing dignitaries. Co-ordination, management, planning and attendance related to or an actual ministerial event, regardless of the level of participation by developing countries, does not form an integral part in delivery aid.

Note: Particularly in the Pacific, such meetings represent a significant proportion of Australia's engagement activities with developing countries to enhance prosperity across the region. As such, the reporting of these key meetings and other engagement with developing countries is captured and reported as part of the broader Official Support for Developing Countries.

d. Multilateral and regional peace and security organisations includes core funding for peace and security organisations not listed on Annex 2 of the DAC's Converged Statistical Reporting Directives (DAC Directives) to support sustainable development and are not project specific.

Example: 
The Pacific Transnational Crime Network (PTCN) is funded by the Australian Federal Police (AFP) and provides police-led proactive criminal intelligence and investigative capability to combat transnational crime in the Pacific through a multi-agency and regional approach.

The Network includes 25 locally staffed Transnational Crime Units (TCU's) located within 17 Pacific Island countries. The Pacific Transnational Crime Coordination Centre (PTCCC) based in Apia, Samoa, performs the central co-ordination role of managing, enhancing, and disseminating law enforcement intelligence products produced by the PTCCC, PTCN member countries and other international law enforcement partners. Membership includes non-ODA eligible countries Australia, New Zealand, Guam, New Caledonia and French Polynesia.

The PTCN also partners with a number of Pacific-based stakeholder organisations (both ODA and non-ODA eligible) including: The Pacific Islands Forum; Oceania Customs Organisation; Pacific Immigration Directors Conference; Pacific Islands Forum Fisheries Agency; Pacific Patrol Boat Program; and Financial Intelligence Units.

Broader PTCN activities provide the Pacific Islands law enforcement decision makers with a broad operational-level overview of the transnational crimes being committed across the region, in addition to an intelligence-informed strategic forecast of the preeminent transnational crime risks and trends impacting on the Pacific region. The PTCCC also produces a suite of intelligence products, including the bi-annual Pacific Illicit Drug Seizures Assessment to specifically inform the law enforcement community of the current illicit drug trafficking trends in the Pacific.

While it is recognised that the efforts of PTCN support regional law development, the work undertaken focuses on regional challenges faced by both developing and developed countries. As such, the provision of funding to support the network's operations (which are also beneficial to developed countries Australia, New Zealand, New Caledonia, Guam and French Polynesia) is not ODA reportable but reported under the broader sustainable development measures.

e. Other security engagement not further defined for any other engagement that cannot be attributed to a defined strategic policy engagement category.

\section{Peace Assistance and Support}

a. Peacekeeping missions encompasses the non-ODA contribution provided for United Nations peacekeeping missions and other regional-based missions that are not ODA. Support provided by Australia for peacekeeping missions aims to improve the overall stability within developing countries and is considered essential for sustainable development. At present, 15 per cent of Australia's contribution is reported as ODA (in line with DAC Directives) and the remaining proportion reported as part of the broader Official Support for Developing Countries.

b. Other (non-ODA) humanitarian support provided by defence and uniformed security forces encompasses a range of activities delivered by the Australian Defence Force (ADF) following an environment disaster. For example, it is common practice for $\mathrm{ADF}$ to utilise ADF personnel during 'friendly exchanges/exercises' to build schools, medical facilities, sanitation blocks, housing and other community infrastructure in developing countries. While delivering a specific benefit to the developing country the program is part of ADF's effort to 
train and develop their personnel in trade corps, such as engineering, carpentry, plumbing, electrical, etc.

Other non-ODA humanitarian assistance also includes: infrastructure assessment and geocoding following disaster or conflict and post-conflict weapons destruction and mine clearance in public areas.

Note: expenditure of a similar nature but not following an environment disaster are excluded from this category. These expenses are to be reported under Uniformed in-field exchanges and operational support.

Example: As part of Australia's humanitarian response for Fiji in the wake of Tropical Cyclone Winston, ADF delivered 60 tonnes of emergency relief supplies and around 760 Australian Defence Force personnel (including engineers, carpenters, electricians and plumbers) to provide ODA humanitarian assistance. Following the ODA response, around 200 ADF personnel were left behind to assist in a joint co-operation with the Republic of Fiji Military Forces to clean-up. The additional assistance helped repair:

- 9 schools, 3 medical centres, 5 community centres and 4 churches.

- Power to 4 villages, water facilities to 700 people and construction of large temporary shelters.

- 340 engineer assessments of infrastructure.

c. Military and police academy education exchanges encompasses formal training placements at academies and colleges. The institutions include defence universities such as Australian Defence Force Academy (ADFA) as well as non-defence education institutions. The recipient will receive formal qualifications (degree or certificate equivalent).

Example: The Jakarta Centre for Law Enforcement Cooperation is a joint Indonesian-Australian academic facility. Through this facility the AFP has delivered a range of supporting and capacity building activities to the Indonesia National Police in order to assist them in their ongoing efforts to counter terrorism, including investigations and intelligence training, crime scene management and post blast response, forensic disciplines and major criminal investigation management.

d. Uniformed in-field exchanges and operational support encompass 'friendly' exchanges and field exercises of uniform personnel as part of a co-operation programme between Australia and developing countries to promote joint capability, fostering international co-operation and trust building between countries. The exchange can include building community infrastructure as well as training of Australian defence personnel and foreign defence members.

Example: ADF and Republic of Fiji Military Forces (RFMF) soldiers conducted training in Counter Improvised Explosive Device (CIED) scenarios in Nadi and the Nausori Highlands. https://fijisun.com.fj/2017/09/23/australia-fijian-soldiers-injoint-training-exercise/

e. Other civil service and field exchanges is similar to the uniformed in-field exchange but for non-uniformed security personnel. 
f. Other peace assistance not further defined for any other peace assistance that cannot be attributed to a category listed above.

\section{Security Assistance and Support}

\section{a. Governance}

- Accountable authorities encompasses the provision of support for the establishment and operation of entities to pursue criminal investigation and prosecution, including war crime tribunals and courts.

- Example 1: Funding by the Australian Attorney-Generals Department (AGD) to the International Crime Cooperation Central Authority to work with counterparts in other countries to ensure foreign evidence to support criminal proceedings and those involved in criminal activities are brought to justice.

- Example 2: The Australian AGD provides core funding to the Countering Foreign Terrorist Fighters (CFTF) to strengthen international crime cooperation (mutual assistance requests) relationships with key countries in Asia and the Middle East to support Australian law enforcement efforts to disrupt, investigate and prosecute terrorism. Through this support the AGD also works with partner countries to (i) strengthen their capacity to respond to Australia's international crime co-operation requests (extradition and mutual legal assistance); and (ii) assists partner countries to strengthen counter terrorism and counter-financing of terrorism legal frameworks.

- Anti-bribery and corruption undermines fair competition and can have disastrous consequences for developing economies, distorting markets, artificially inflating prices, undermines product quality and ultimately shrinks global markets for exports and investment. This category includes the operational aspects of surveillance and monitoring, intel sharing and prosecution of officials to support better governance and legal systems.

- Civil disobedience control

\section{b. Transnational crime (investigation and response)}

Includes activities intercepting and prosecuting for crimes that have actual/ potential effect across national borders or crimes that are intrastate but offend the fundamental values of the international community. Included are response actions such as monitoring, investigation, extradition, prosecution and mutual legal assistance.

- Transnational migration (human trafficking and people smuggling) encompasses human trafficking, slavery and slavery-like practices such as servitude, forced labour and forced marriage are complex crimes and a major violation of human rights.

- Goods control (contraband smuggling) encompasses the operational restrictions of prohibited or contraband goods and services. Includes joint operations preventing movement of illegal drugs, weapons, illegally logged timber, biological organs, and other restricted goods and services such as medications, tobacco and alcohol. 
- Mechanisms and interventions to control information are excluded from this category, for personal information interventions refer to information security and for business intelligence control refer to infrastructure and asset security.

- Example 1: Operation Valencia was an investigation conducted by the NSW Joint Organised Crime Group (JOCG) - comprising members from the Australian Federal Police (AFP), New South Wales Police, Australian Border Force (ABF), Australian Criminal Intelligence Commission (ACIC) and the New South Wales Crime Commission (NSWCC) which included significant co-operation from Taskforce Blaze in China, co-ordinated by the AFP's Guangzhou Post. https://www.afp.gov.au/news-media/media-releases/joint-operation-stops101-million-crystal-methamphetamine-hitting

- Example 2: A joint investigation involving the Australian Federal Police (AFP), RSIPF, the United States Drug Enforcement Administration (DEA), the Australian Criminal Intelligence Commission (ACIC), NSW Police Force (NSWPF) and Australian Border Force (ABF) in cocaine smuggling in the Solomon Islands.

https://www.afp.gov.au/news-media/media-releases $/ 500 \mathrm{~kg}$-cocaineseized-solomon-islands-two-arrested-sydney-part-joint

- Anti-poaching, wildlife and marine life protection encompasses the operational interventions to disrupt the illegal trespass on a developing country's property, including theft and hunting of wildlife, destruction of habitats and ecosystems, and illegal fishing. Includes joint collaboration field efforts patrolling and intelligence sharing, ground logistic support and assistance, exchange of surveillance information.

- Example: ADF Pacific Patrol Boat Program contributes to maritime security in the Pacific, assisting our neighbours to develop the capacity to protect their maritime economic resources. The patrol boats are owned, operated and maintained by Pacific Island countries and technical and operational support is provided by in-country Royal Australian Navy Maritime Surveillance Advisers and Technical Advisers. Defence also provide funding to support capability development in infrastructure, logistics, and training and skills development.

- Intelligence gathering and sharing encompasses the establishment of centres, agencies and the like and the ongoing operation (administration/overhead) of these network groups.

- Criminal justice and enforcement encompasses the assistance and support provided to prosecute crime.

- Counter terrorism encompasses all activities addressing counter terrorism in all its forms, including capacity building in the form of training, policy reforms, system development, drafting of legislation, etc.

- Example 1: The Operation Alliance deployment of a specialist AFP response team to Indonesia, at the request of the Indonesian National Police (INP), to assist in the immediate aftermath of the explosions. The immediate assistance provided by the AFP included specialist victim 
identification officers, scientific crime scene investigators and post-bombblast investigators

- Example 2: The AFP deployment of a dedicated Counter Terrorism Police Advisor based in Jakarta and embedded in the Indonesian National Police Headquarters to undertaken preventive investigations and work in close liaison with international law enforcement partners.

- Example 3: Australian Defence annual counter terrorism exercise with the Philippine defence force, building operational and command-level planning and tactical skills.

- Example 4: The Australian Department of Foreign Affairs commissioned a research study from the Asia Foundation's Conflict and Development Team on the role of development assistance countering terrorism in Asia.

\section{c. Infrastructure and asset security}

This category includes operational interventions to protect critical assets and excludes information technology systems (infrastructure) or digital assets. Operational activities of this nature are to be reported under Information Security.

- Infrastructure protection includes operational interventions to protect airports, highways rail transport, hospitals, bridges, transport hubs, network communications, media, the electricity grid, dams, power plants, seaports, oil refineries, and water systems. It covers security zoning and physical security control measures of facilities and the provision of personnel security services to undertake infrastructure and asset protection.

- Monetary fraud management and tracking includes operational interventions regarding financial asset misappropriation, such as the tracking and seizure of funds diverted for terrorism.

- Intellectual property and trade secrets encompasses the investigation and persecution of intellectual property and trade secret theft detrimental to free trade engagement with developing countries, including enforced adherence to industrial property protection mechanisms.

\section{d. Information security}

This category includes operational interventions by donor security personnel to prevent the unauthorised access, use, disclosure, recording and destruction of information. These activities can be undertaken jointly with security personnel from ODA-eligible countries or on behalf of them. The category captures the operationalisation of policing and security.

This category does not include information security activities that build the capacity of developing country security personnel (excluding military) to allow them to self-manage their operations or the provision of equipment such as malware or other IT systems assessed as ODA.

- Cyber security includes the operational policing to protect computer systems from theft or damage covering hardware, software and electronic data.

- Identity fraud includes active policing to investigate and prosecute identify fraud, including consumer fraud and other forms of electronic malicious deception. 
- Information protection and security checks includes the undertaking of personal security checks and the sharing of intelligence gathered information. It also includes any personnel security checks under Data Protection legislation or equivalent.

\section{e. Other security assistance and support}

This category operates as a residual classification. The category recognises that building long-term peace and stability is separate from the work of long-term human development. Enhancing the capabilities of developing countries to effectively manage their peace and security, provides long-term viability, recognising that a stable environment is critical to ongoing development.

- Operational security captures: in-field activities (including training) that crosses over to operational which cannot be attributed to a category listed above or capacity building that cannot be reported as ODA.

- Other (non-ODA) expenses incurred in delivery assistance captures expenses incurred by the donor as part of an ODA activity but are not ODA reportable. This category recognises that these expenses are incurred by the donor as part of their effort to deliver assistance and include capital assets owned by the donor.

- Other security assistance not further defined includes any other security operational activities that cannot be attributed to other security assistance not further defined categories. 


\section{References}

Abt, T. and C. Winship (2016), What Works in Reducing Community Violence, USAID,

Democracy International, https://www.usaid.gov/sites/default/files/USAID-2016-What-

Works-in-Reducing-Community-Violence-Final-Report.pdf.

African Union (2014), Common African position (CAP) on the post-2015 development agenda, https://au.int/sites/default/files/documents/32848-doc-common_african_position.pdf.

Aid, R. (ed.) (2006), The Securitization of Development Aid, Reality of Aid, http://www.realityofaid.org/wp-content/uploads/2013/02/RoA-Report-2006-Part-II.pdf.

Bejraoui, A. and V. Gaveau (2019), Treatment of contributions to peace and security in the TOSSD framework - recommendations to the TOSSD Task Force, http://www.oecd.org/dac/financing-sustainable-development/development-financestandards/recommendations-to-TF.pdf (accessed on October 2019).

Benn, J. and V. Gaveau (2018), Example of a development enabler at regional level: Peace and security, http://www.oecd.org/dac/financing-sustainable-development/development-financestandards/Item $\% 203 \% 20-\% 20$ Peace $\% 20$ and $\% 20$ security.pdf.

Bergenas, J. and G. Mahoney (2016), SDG 16: A platform for a new era of international cooperation, Impakter, https://impakter.com/sdg-16-platform-new-era-internationalcooperation.

Civil Society Organisations (2019), "Tracking support to Sustainable Development Goals - the case of peace and security" - A submission from civil society organisations working on peace and sustainable development, https://www.oecd.org/dac/financing-sustainabledevelopment/development-financestandards/CSO $\% 20$ submission $\% 20$ on $\% 20$ TOSSD $\% 20$ security $\% 20$ assistance $\% 20$ March $\% 20$ 2019.pdf.

Cling, J., M. Razafindrakoto and F. Roubaud (2018), SDG 16 on Governance and its measurement: Africa in the Lead, DIAL (Développement, Institutions et Mondialisation), http://en.dial.ird.fr/content/download/298851/4609078/version/1/file/2018-02+-+SDG+16++ Africa + in + the + Lead.pdf.

Éditions OCDE, P. (ed.) (2019), Nigeria's perspective on Total Official Support for Sustainable Development (TOSSD), OECD Development Co-operation Working Papers $n^{\circ}$ 56, https://doi.org/10.1787/619cb021-en.

Ferdi (ed.) (2016), Linking security and development - A Plea for the Sahel, Ferdi, https://ferdi.fr/en/publications/linking-security-and-development-a-plea-for-the-sahel.

Fortna, V. (2004), "Does Peacekeeping Keep Peace? International Intervention and the Duration onal Intervention and the Duration", International Studies Quarterly, Vol. 48(2), pp. 269 292, http://www.columbia.edu/ vpf4/pkISQ\%20offprint.PDF. 
Gaveau, V., A. Bejraoui and J. Benn (2019), Draft terms of reference for the pilot study on the treatment of peace and security in TOSSD, http://www.oecd.org/dac/financing-sustainabledevelopment/development-finance-standards/ToRs-TOSSD-pilot-study-Peace-andSecurity.pdf.

Harborne, B., W. Dorotinsky and P. Bisca (2017), Securing Development : Public Finance and the Security Sector, World Bank, https://openknowledge.worldbank.org/handle/10986/25138.

Hegre, H., L. Hultman and H. Nygård (2019), "Evaluating the conflict-reducing effect of UN peacekeeping operations", The Journal of Politics, Vol. 81(1), pp. 215-232, https://www.prio.org/utility/DownloadFile.ashx?id=1700\&type=publicationfile.

International Task Force on Global Public Good (2006), Expert Paper Serires Five: Peace and Security.

Krisch, M. et al. (2018), Global strategies to reduce violence by 50\% in 30 Years: Findings from the WHO and University of Cambridge Global Violence Reduction Conference 2014, https://www.vrc.crim.cam.ac.uk/system/files/documents/violencereductionreport.pdf.

Saferworld (2014), From the Sustainable Development Goals to the Post-2015 Development Agenda: Building a Consensus for Peace, https://www.saferworld.org.uk/downloads/pubdocs/building-a-consensus-for-peace.pdf.

Special Committee on Peacekeeping Operations (2018), Report of the Special Committee on Peacekeeping Operaion, A/72/19, https://digitallibrary.un.org/record/1627951? $1 \mathrm{n}=\mathrm{en}$.

TOSSD Task Force (2018), Fourth meeting of the TOSSD Task Force - main conclusions and action points, http://www.oecd.org/dac/financing-sustainable-development/developmentfinance-standards/4th\%20TOSSD\%20Task\%20Force\%20Action\%20Points.pdf.

TOSSD Task Force Secretariat (2019), Tracking support to SDGs - the case of peace and security, expert meeting, Summary of discussions, http://www.oecd.org/dac/financingsustainable-development/development-financestandards/TOSSD $\% 20 \% 20$ peace $\% 20$ and $\% 20$ security $\% 20$ $\% 20$ summary $\% 20$ expert $\% 20$ meeting.pdf.

Untied Nations and World Bank (2018), Pathways for Peace : Inclusive Approaches to Preventing Violent Conflict, World Bank, https://openknowledge.worldbank.org/handle/10986/28337.

Weisburd, D. et al. (2017), "What Works in Crime Prevention and Rehabilitation : An Assessment of Systematic Reviews", Criminology and Public Policy, Vol. 16, pp. 415-449, https://onlinelibrary.wiley.com/doi/full/10.1111/1745-9133.12298. 


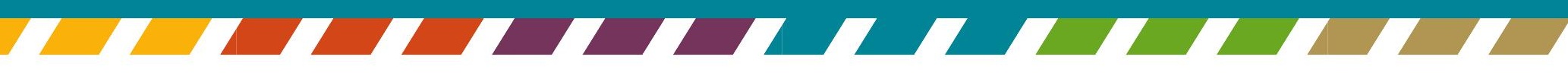

